\title{
O pequenos partidos e as disputas eleitorais no Brasil - uma análise de desempenho entre 1998-2014
}

Leonardo da Silveira Ev'

\section{Resumo}

Este artigo visa a contribuir com o estudo dos pequenos partidos brasileiros por meio da análise de seus desempenhos em eleições e de suas características organizacionais. Discutem-se possíveis critérios de como estabelecer quais são as pequenas legendas dentre os quais se escolhe um e OPTANDO-SE POR UM a partir do qual se selecionam os casos. Analisam-se dados eleitorais referentes às disputas para executivo e legislativo nos três níveis federativos do grupo de partidos selecionados, relacionando os desempenhos dos pequenos partidos às suas características organizacionais. A análise aponta que os partidos que apresentam maior capilaridade e menor institucionalização de seus diretórios subnacionais têm melhor performance no período analisado.

Palavras-chave: Pequenos partidos. Eleições. Sistema partidário.

\section{Introdução}

Ao longo dos últimos anos, os estudos sobre partidos brasileiros têm voltado sua atenção a um tipo particular de legenda que, tradicionalmente sempre ocupou um espaço marginal na literatura: os pequenos partidos (DANTAS; PRAÇA, 2004, 2010; LACERDA; MOURA, 2010; EV; MELO, 2014; CALVO, GUARNIERI; LIMONGI, 2015; EV, 2015; NASCIMENTO et al., 2016; SILVA et al., 2016; PAIVA, ALVES; BENEDITO, 2017). Em boa medida, o interesse por estes atores decorre

I Doutorando no Programa de Pós-Graduação em de Ciência Política da Universidade Federal de Minas Gerais (PPGCP-UFMG). E-mail: leo.sel987@gmail.com

$((c))$ EY
Direito autoral e licença de uso: Este artigo está licenciado sob uma Licença Creative Commons. Com essa licença você pode compartilhar, adaptar, para qualquer fim, desde que atribua a autoria da obra, forneça um link para a licença, e indicar se foram feitas alterações. 
do aprofundamento do processo de fragmentação do sistema partidárioº cujos principais responsáveis são os pequenos partidos. Com efeito, tomando-se como referência a primeira eleição para o Congresso após o fim do bipartidarismo, realizada em 1982 ainda sob a vigência do regime militar, o sistema partidário brasileiro atual tem sete vezes mais partidos.

Boa parte das novas legendas partidárias pode ser considerada como pequena quando se leva em consideração sua capacidade de obter votos e eleger candidatos relativamente aos demais partidos. Ev e Melo (2014) calculam que cerca de $60 \%$ dos partidos brasileiros estão entre aqueles de menor porte e afirmam que estes têm apresentado aumento progressivo de sua participação no total de votos em eleiçóes. Tal crescimento - tanto em termos quantidade, quanto em votação - tem implicaçóes para a democracia brasileira no que se refere à estruturação da competição eleitoral, à representação política e às dinâmicas de governo no âmbito do presidencialismo de coalisão.

Nessa perspectiva, a maioria dos estudos com foco nos pequenos partidos procura analisar como estes se inserem no sistema político mediante suas estratégias de competição política. O ponto de partida, grosso modo, é que, em virtude de suas dimensóes reduzidas, os pequenos partidos teriam maiores dificuldades de disputar e conquistar votos e cargos, de sorte que se veem obrigados a lançar mão de estratégias específicas para conseguirem ser eleitoralmente bem-sucedidos. Assim, as costuras de coligaçóes eleitorais dos pequenos partidos e os seus resultados efetivos têm sido objeto de grande interesse (DANTAS; PRAÇA, 2004, 2010; CALVO, GUARNIERI; LIMONGI, 2015; SILVA et al., 2016; PAIVA, ALVES; BENEDITO, 2017). Outra abordagem procura entender como algumas características dos partidos - tais como a capilaridade, a centralização decisória e o perfil ideológico determinam sua capacidade de lançar candidaturas competitivas e maximizar suas chances de vitória (LACERDA; MOURA, 2010; EV; MELO, 2014; EV, 2015). Há também análises que demonstram o papel que os pequenos partidos têm nas eleiçóes e no sistema partidário em termos de seu impacto na volatilidade e na fragmentação (NASCIMENTO et al., 2016).

2 Atualmente existem 35 partidos com registro no Tribunal Superior Eleitoral, de acordo com informações do órgão: http://www.tse.jus.br/partidos/partidos-politicos/registrados-no-tse. 
Longe de corroborar a ideia de que os pequenos partidos são um grupo de legendas genéricas cuja única ambição é aproveitar as brechas e facilidades existentes no arranjo institucional brasileiro, o quadro que emerge dos estudos mostra que estes têm atuado de forma estratégica e, em certos casos, eficiente. Algumas siglas lograram crescer ao longo das últimas décadas e expandir sua influência na política. Elas têm protagonizado dinâmicas importantes na política nos âmbitos regional e nacional e se tornaram atores que não podem ser ignorados pelos grandes partidos.

Por essas razóes, o estudo dos pequenos partidos tenderá a ser cada vez mais importante na agenda de pesquisa da ciência política brasileira. O presente artigo é uma contribuição ao entendimento desses atores. A análise empreendida aqui apresenta o desempenho dos pequenos partidos selecionados em todos os níveis de competição (municipal, estadual e nacional) para cargos legislativos e executivos entre 1998 e 2014. Relacionamos os distintos resultados ao perfil dos pequenos partidos de acordo com a tipologia proposta por Ev (2015) para explicá-los.

$\mathrm{O}$ artigo está dividido em seis seçóes. A primeira seção, após a introdução, discute o problema da definição de pequenos partidos, bem como apresenta a que é utilizada neste estudo e os casos analisados. Na segunda etapa, são descritos os resultados eleitorais dos partidos no período de análise. Em seguida, a terceira e quarta seções relacionam os resultados aos perfis distintos dos pequenos partidos e às suas capacidades organizacionais. Finalmente, a última parte traça perspectivas de evolução desses partidos no futuro.

A contribuição que o artigo busca proporcionar é a de relacionar uma tipologia de pequenos partidos às suas distintas capacidades de desenvolvimento e indicar o impacto que estas têm sobre o desempenho desse conjunto de legendas. Trata-se de tema ainda náo investigado pela ciência política brasileira, a qual ainda não procurou fazer distinçóes qualitativas entre as pequenas legendas, tampouco compreender com maior profundidade porque algumas delas são mais bem-sucedidas eleitoralmente do que as demais. 


\section{Pequenos partidos: em busca de uma definição}

O que faz um partido ser pequeno? Esta é uma pergunta para a qual não há, até agora, uma resposta consensual na literatura. Tendo-se em vista que se trata de uma medida relacional, isto é, um partido somente é pequeno quando comparado a partidos maiores, os estudos que analisam esse conjunto de legendas têm adotado uma ampla gama de indicadores e procedimentos para estabelecer um limiar de corte (PAIVA; ALVES; BENEDITO, 2017). Assim, pode-se argumentar em favor de uma série de indicadores de grandeza, cada um enfatizando uma dimensão específica dos partidos, tais como: a quantidade de filiados, o grau de capilaridade, o nível de financiamento, a quantidade de votos e cargos, a presença em coalizóes de governo, sua notoriedade na esfera publica, dentre outros. Entretanto, uma dimensão tem prevalecido sobre as demais nos estudos feitos até o momento: a capacidade de obtenção de votos.

A votação para a Câmara dos Deputados tem sido o principal critério utilizado pela literatura para distinguir os partidos brasileiros de acordo com sua relevância na política nacional e identificar quais deles poderiam ser considerados como pequenos, conforme constatam Nascimento et al. (2016). Tal opção salienta aquela que é a principal característica de partidos políticos, qual seja a disputa por cargos eletivos (DOWNS, 1999). Dessa forma, partidos relevantes são aqueles capazes de influenciar o jogo político ocupando as posiçóes de poder no estado. Os critérios de Sartori (1976), que definem a relevância de um partido pelo seu potencial de chantagem ou por sua capacidade de ser um ator pivotal, são um ponto de partida para o estabelecimento de um critério de corte. Entretanto, o autor não define uma operacionalização específica.

Diante da falta de uma definição universalmente aceita, os estudiosos têm utilizado a votação obtida pelos partidos como um indicador do que seria sua relevância dentro do sistema político. Afinal, é pela competição por cargos eleitorais que um partido se promove e mobiliza apoio da sociedade e é com a conquista de cargos que eles exercem seu quinhão de poder. Desta feita, o nível de apoio eleitoral é tomado como um indicador aproximativo de quanto poder os partidos é capaz de mobilizar. 
Dantas e Praça (2004) definem os pequenos partidos como aqueles que: i) não elegeram candidatos para a legislatura de 1999-2003; ii) cujos eleitos abandonaram a sigla; iii) obtiveram menos de $1 \%$ dos votos nas eleiçóes de 1998 para a Câmara dos Deputados; iv) que obtiveram menos de $1 \%$ do fundo partidário distribuído em 2000. Em uma análise posterior, os autores mantêm esse patamar de votos como critério, mas estendem sua aplicação às eleiçóes de 2002 e 2006, exigindo que tal patamar se verifique em pelo menos duas delas (DANTAS; PRAÇA, 2010). Em ambos os estudos, o grupo de partidos definidos como pequenos é muito similar, exceção feita ao PV - que deixa de ser considerado pequeno no estudo mais recente - e aos partidos extintos entre as duas publicaçóes.

Um percentual fixo de votação também é utilizado por Ev e Melo (2014) para delimitar o grupo das pequenas legendas. Os autores consideram como pequenos aqueles partidos que obtiveram votaçáo inferior a 2,5\% dos votos válidos em pelo menos duas eleiçóes, considerando-se a votação para a Câmara dos Deputados nos anos de 1998, 2002, 2006 e 2010. A aplicação desta linha de corte classifica 15 partidos como sendo pequenos, os mesmos identificados por Ev (2015), que adota o mesmo patamar de votos, mas eleva sua exigência para três pleitos no mesmo intervalo. O mesmo percentual de votos para a Câmara dos Deputados é utilizado por Paiva, Alves e Benedito (2017), que ampliam a série de eleiçóes incluindo a de 2014 e mantêm a exigência de três pleitos com votação inferior a 2,5 por cento. Com a extensão da série temporal, 19 partidos são classificados como sendo de pequeno porte, os mesmos 15 de Ev e Melo (2014) e Ev (2015) acrescidos de quatro legendas surgidas após 2014.

Duas abordagens mantêm o critério eleitoral para a definição, mas não adotam o procedimento de fixar um patamar de votação (SILVA et al., 2016; NASCIMENTO et al., 2016). Em ambas, a definição de pequenos partidos é dada por meio de análise de cluster, que distribui os casos analisados em grupos e maximiza a homogeneidade das observaçóes dentro dos grupos e a heterogeneidade entre grupos. Para tanto, os autores consideram o percentual de votação dos partidos brasileiros para a Câmara dos Deputados entre 1998 e 2014 em cada uma das Unidades da Federação. A divisão dos partidos em clusters feita para cada Unidade da Federação (UF) 
classifica-os entre pequenos, médios ou grandes a partir dos percentuais de votação obtidos por eles nestas arenas. Dessa forma, um partido que é pequeno em um estado, pode ser médio ou grande em outro e todas as legendas com registro no Tribunal Superior Eleitoral (TSE) são passíveis de ser consideradas como um partido pequeno em alguma UF.

Dois outros estudos (LACERDA; MOURA, 2010; CALVO, GUARNIERI; LIMONGI, 2015) não especificam um critério de distinção dos pequenos partidos em relação aos demais. Lacerda e Moura (2010) abordam exclusivamente os pequenos partidos de esquerda - Partido Comunista Brasileiro (PCB), Partido da Causa Operária (PCO), Partido Socialista dos Trabalhadores Unificado (PSTU) e Partido Socialismo e Liberdade (PSOL) - identificados pelos autores como "esquerda radical". Já Calvo, Guarnieri e Limongi (2015) não explicitam quais partidos formam o grupo de pequenos, limitando-se a indicar que são partidos LEGENDAS que rebem parcelas menores de votos nos distritos em que concorrem e nas suas coalizóes, de modo que não fazem uma definição a priori, mas condicionada à votação relativa dos partidos incluídos.

E, qualquer que seja a estratégia de classificação empregada, existem vantagens e desvantagens em qualquer uma das estratégias de classificação empregadas UM DOS MÉTODOS EMPREGADOS. Os autores que escolhem fixar uma quota de votos a ser obtida pelos partidos, tendo como referência os pleitos para a Câmara dos Deputados, chegam a resultados muito parecidos em termos de quais partidos seriam considerados pequenos $^{3}$. Essa perspectiva enfatiza as legendas como organizaçóes e sua grandeza em comparação com as demais no nível nacional agregado. Trata-se de um procedimento simples e de fácil operacionalização que indica claramente quais partidos compóem o grupo de pequenos.

Entretanto, críticos desse procedimento afirmam que a simples fixação a priori de um patamar de votos é um critério demasiadamente aleatório e que não é capaz de traduzir a real grandeza das legendas em termos da disputa eleitoral nos verdadeiros distritos, os estados. Nascimento et al. (2016)

3 A maior variação entre os estudos é fruto da entrada e saída de partidos do sistema partidário, que ocorre ao longo dos diferentes anos das distintas publicações. 
comparam as definiçóes realizadas a partir desse critério com sua própria, feita através da análise de cluster com a votação de todas as legendas em cada estado. Eles apontam, através de teste-T e de ANOVA, que sua definição produz categorias com maior homogeneidade interna e maior heterogeneidade externa em relação aos demais estudos. Com efeito, esse tipo de procedimento tem o mérito de abarcar melhor a complexidade da disputa eleitoral para a Câmara dos Deputados ao acessar a arena na qual elas ocorrem. Entretanto, o método usado pelos autores náo produz um grupo coeso de legendas consideradas pequenas. Como a força eleitoral dos partidos varia muito a depender dos estados, as legendas que são consideradas pequenas em um, podem ser de médio ou grande porte em outro; além disso, partidos que dificilmente seriam considerados pequenos quando tomados nacionalmente - como PT, PMDB ou PSDB - são, em alguma medida, pequenos segundo os resultados obtidos por esse método.

As distinções apontadas revelam que os dois tipos de procedimento enfatizam dimensôes diferentes para medir a grandeza de um partido. A fixação de um patamar de votos considera as legendas como um todo e pensa a ideia de sua relevância em termos de sua DA capacidade de exercer poder no plano nacional, decorrente de eleger bancadas na Câmara dos Deputados. A lógica subjacente é bastante simples: partidos pouco relevantes são aqueles que obtêm votação residual frente aos demais e elegem bancadas comparativamente pequenas incapazes de influência significativa nas decisóes políticas importantes. Trata-se de uma perspectiva em sintonia com os já referidos critérios de Sartori (1976), que enfatizam a capacidade de um partido exercer influência sobre o poder político. A análise da votação feita em cada distrito, por outro lado, conquanto metodologicamente mais refinada e meticulosa empiricamente, acaba por perder de vista a dimensão mais integrativa do sistema partidário. Ao tratar cada nível subnacional como uma arena independente, essa abordagem não considera que as legendas brasileiras são organizaçóes nacionais que se coordenam nos diferentes níveis e que é no nível federal que se situa seu centro decisório. Assim, embora tal método seja adequado para medir o impacto que os pequenos partidos têm na competiçáo dentro do distrito eleitoral, ela não necessariamente indica a relevância dessas mesmas legendas em termos substantivos, sobretudo em nível nacional. 
Dessa forma, a opção feita no âmbito deste artigo, em sintonia com outros estudos (EV; MELO, 2014; EV, 2015; PAIVA, ALVES; BENEDITO, 2017), é a de considerar como pequenos os partidos que obtiveram votação inferior a 2,5\% para a Câmara dos Deputados em pelo menos três das quatro eleiçóes do período 1998-2014. Esta opção delimita um grupo claro de legendas, apresentadas no Quadro 1, que terão seu desempenho eleitoral analisado na próxima sessão.

\section{Quadro I - Pequenos partidos analisados*}

\begin{tabular}{|c|c|c|}
\hline Sigla & Nome & Registro \\
\hline PCB & Partido Comunista Brasileiro & $09 / 05 / 1996$ \\
\hline PCO & Partido da Causa Operária & $30 / 09 / 1997$ \\
\hline PHS & Partido Humanista da Solidariedade & $20 / 03 / 1997$ \\
\hline PMN & Partido da Mobilização Nacional & $25 / 10 / 1990$ \\
\hline PRB & Partido Republicano Brasileiro & $25 / 08 / 2005$ \\
\hline PRP & Partido Republicano Progressista & $29 / 10 / 1991$ \\
\hline PRTB & Partido Renovador Trabalhista Brasileiro & $18 / 02 / 1997$ \\
\hline PSC & Partido Social Cristão & $29 / 03 / 1990$ \\
\hline PSDC & Partido Social Democrata Cristão & $05 / 08 / 1997$ \\
\hline PSL & Partido Social Liberal & $02 / 06 / 1998$ \\
\hline PSOL & Partido Socialismo e Liberdade & $15 / 09 / 2005$ \\
\hline PSTU & Partido Socialista dos Trabalhadores Unificado & $19 / 12 / 1995$ \\
\hline PT do B & Partido Trabalhista do Brasil & $1 / 1 / 10 / 1994$ \\
\hline PTC & Partido Trabalhista Cristão & $22 / 02 / 1990$ \\
\hline PTN & Partido Trabalhista Nacional & $02 / 10 / 1997$ \\
\hline
\end{tabular}

* Dados extraídos do Tribunal Superior Eleitoral. Disponivel em: http://www.tse.jus.br/partidos/partidos-politicos/registrados-no-tse. Acessado em: agosto de 2018

Fonte: Elaborado pelo autor (2019). 


\section{Os pequenos partidos nas eleições 1998 - 2014}

Nesta seção, serão analisados os dados relativos à votação e à quantidade de candidatos eleitos pelos pequenos partidos nas eleiçóes municipais e nacionais no período entre 1998 e 2014 . Como a grande maioria dos partidos incluídos na análise obteve seu registro definitivo no período entre 1995 e 1997, optou-se por excluir os pleitos anteriores a 98 mesmo que alguns dos partidos estudados já existissem desde a década de 1980, como é o caso de PSC e PTC. Dessa forma, o período analisado compreende os pleitos nos quais a grande maioria dos pequenos partidos participou, as únicas duas exceções tardias são PSOL e PRB, que surgiram em 2005 e 2006 respectivamente. A intenção é ver a evolução dos pequenos partidos e identificar as variaçóes entre eles ao longo do tempo no que se refere à ampliação de sua votação e ao número de candidatos eleitos, o que produz, assim, um diagnóstico de sua performance.

Para fins de análise, retomaremos a tipologia específica para pequenos partidos criada por Ev (2015) que classifica as legendas abordadas em três grupos de acordo com suas características distintivas. Assim, os pequenos partidos são divididos entre as categorias "pequenos partidos de esquerda", "pequenos partidos personalistas" e "pequenos partidos confessionais". Integram o primeiro grupo o PCB, o PCO, o PSTU e o PSOL. Os partidos personalistas são compostos por PHS, PMN, PRP, PRTB, PSL, PTdoB, PTC e PTN. Por fim, os partidos confessionais são compostos por PSC, PRB e PSDC.

O uso destas categorias permite ganhos analíticos ao aglutinar as legendas em grupos que sintetizam características que os definem e distinguem e a partir das quais é possível compreender suas distintas performances eleitorais. Conforme apontam Ev (2015) e Ev e Melo (2014), as dimensóes de capilaridade e institucionalização variam consideravelmente entre estes partidos em função das características dos três grupos e condicionam, em parte, seu desempenho em pleitos. Como será argumentado ao longo deste artigo, ser um pequeno partido de esquerda, personalista ou confessional condiciona as perspectivas de desenvolvimento da legenda, o que influenciando INFLUENCIA sua capilaridade e sua institucionalização, estas que AS QUAIS, por sua vez, estáo relacionadas ao grau de sucesso eleitoral. 


\section{Gráfico I - Votação para as Câmaras Municipais nos Municípios Brasileiros (2000-20I2)*}

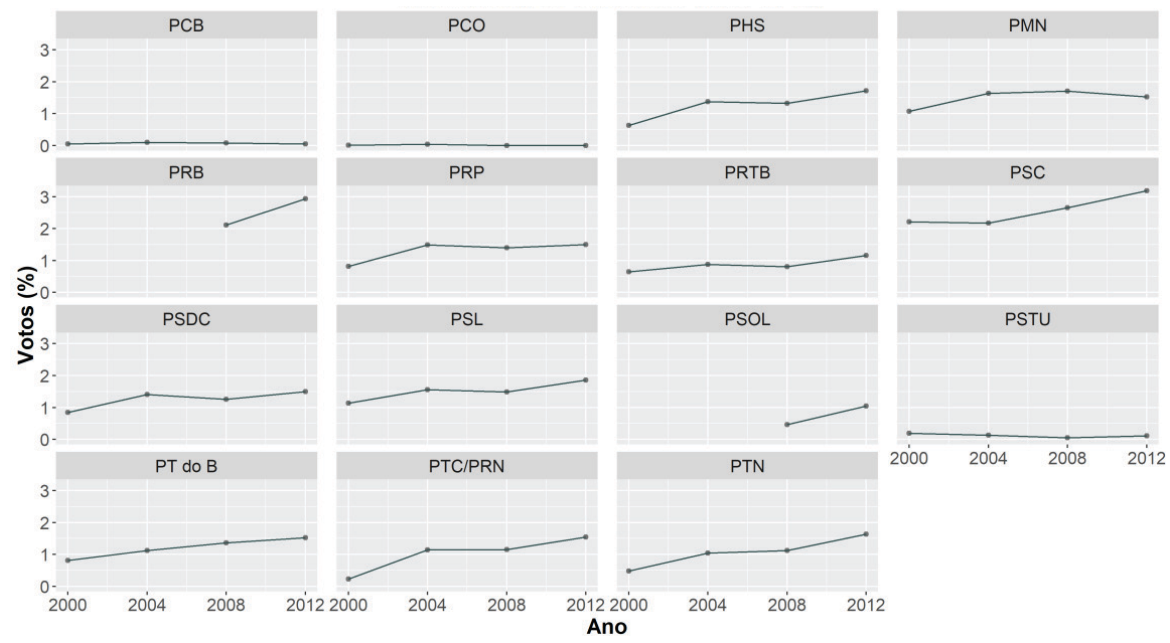

Dados extraídos do Tribunal Superior Eleitoral.

Fonte: Elaborado pelo autor (2019 2018).

As eleiçóes municipais são, dentre todos os pleitos realizados no país, aquelas com maior permeabilidade aos partidos. Os menores municípios possuem magnitude de nove cadeiras, o que significa que o partido que obtiver pouco mais de $11 \%$ dos votos consegue eleger um representante, valor este que pode ser menor, dependendo da votação de outros partidos. Ademais, os custos das campanhas para prefeito e vereador são comparativamente menores, sobretudo se considerarmos que quase $90 \%$ dos municípios brasileiros têm até 50 mil habitantes ${ }^{4}$. Outro fator a ser considerado é a incipiência dos sistemas partidários municipais que, exceção feita a algumas poucas capitais e cidades mais populosas, raramente guardam qualquer semelhança com o sistema nacional, tampouco gozam de grande estruturaçáo. Assim, o local onde os pequenos partidos têm, em teoria, maiores chances de sucesso é nos municípios.

4 Conforme dados do Censo Brasileiro de 2010, realizado pelo Instituto Brasileiro de Geografia e Estatística (IBGE), disponíveis em: https://www.ibge.gov.br/estatisticas/sociais/populacao/9662-censo-demografico-20 I0. html?edicao $=9673 \varepsilon \mathrm{t}=$ destaques. 
Como se pode ver no Gráfico 1, as legendas analisadas tiveram votação relativamente baixa nas disputas para os legislativos municipais no Brasil, durante o período analisado. Somente dois pequenos partidos confessionais, PRB e PSC superaram a marca de 3\% dos votos, ambos no pleito de 2012. Os demais partidos apresentam desempenho estável, oscilando entre 1 e $2 \%$ aproximadamente. Os pequenos partidos de esquerda obtiveram votação praticamente residual, não superando $1 \%$; exceção feita ao PSOL, que é o único expoente desta categoria que incrementa sua votação no período. Os pequenos partidos personalistas, juntamente com o PSDC, têm desempenho comparativamente mediano, com algumas destas legendas, aumentando marginalmente sua votação ao longo do período. Ainda que apresentem individualmente votaçôes pouco expressivas, é importante salientar que o total agregado de votos obtidos por estas legendas nos pleitos analisados evoluiu de $9,14 \%$ nas eleiçóes de 2000 para 21,31\% em 2012.

$\mathrm{Na}$ esfera municipal, os pequenos partidos também disputaram cargos para o executivo e seu desempenho pode ser visto nos dados do Gráfico 2. Novamente, os confessionais PRB e PSC se destacam como casos de legendas que obtêm votação comparativamente maior e que mostram tendência de crescimento ao longo do tempo. A estes se junta uma pequena legenda de esquerda, o PSOL, o qual tem o maior incremento de votos nas duas eleiçôes analisadas. Todos os pequenos partidos personalistas, juntamente com as legendas de esquerda - PCB, PCO e PSTU - e a confessional PSDC, têm votaçáo baixa e estável ao longo do período. 
Gráfico 2 - Votação para Prefeito (200-2012)*

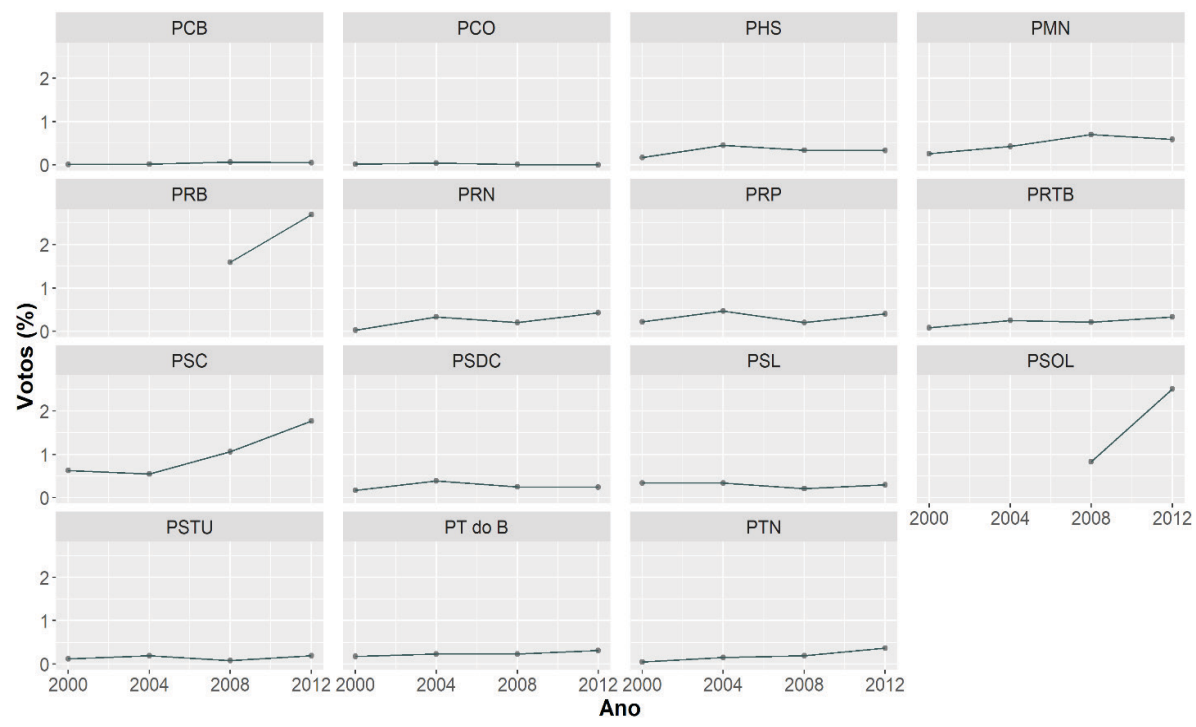

* Dados extraídos do site do Tribunal Superior Eleitoral.

Fonte: Elaborado pelo autor (2019 2018).

No entanto, a proporção de votos obtida pelos pequenos partidos não traduz as diferenças entre eles em termos de conquista de prefeituras, pois alguns deles podem obter votação expressiva em municípios muito populosos e ainda assim não ganhar a prefeitura. Em 2012 o PSOL, por exemplo, obteve 914.082 votos no primeiro turno da disputa pela prefeitura do Rio de Janeiro, mais do que outros 12 pequenos partidos obtiveram em todos os municípios que disputaram e, no entanto, elegeu apenas dois prefeitos. Dado o caráter majoritário da disputa, não há relação direta entre votos obtidos agregados nacionalmente e proporção de prefeituras conquistadas. Assim, a variação nas quantidades de cargos conquistadas é alta entre os partidos analisados, o que aponta a relevância da capacidade de coordenaçáo deles quanto ao lançamento de candidatos e a estratégias de interseção eleitoral, como será argumentado adiante. Os dados da Tabela 1 ilustram esse efeito ao mostrar o percentual de sucesso das candidaturas lançadas por eles aos executivos municipais nas 
quatro eleiçôes analisadas. Particularmente legendas personalistas, como o PRP, o PHS, o PSL e o PMN logram obter aproveitamentos superiores ao PSOL e a outras legendas com maior votação agregada. Este quadro é evidenciado também pelo fato de que os dois partidos eleitoralmente mais bem-sucedidos em termos de votação, PRB e PSC, têm aproveitamento semelhante ou inferior em alguns casos. 


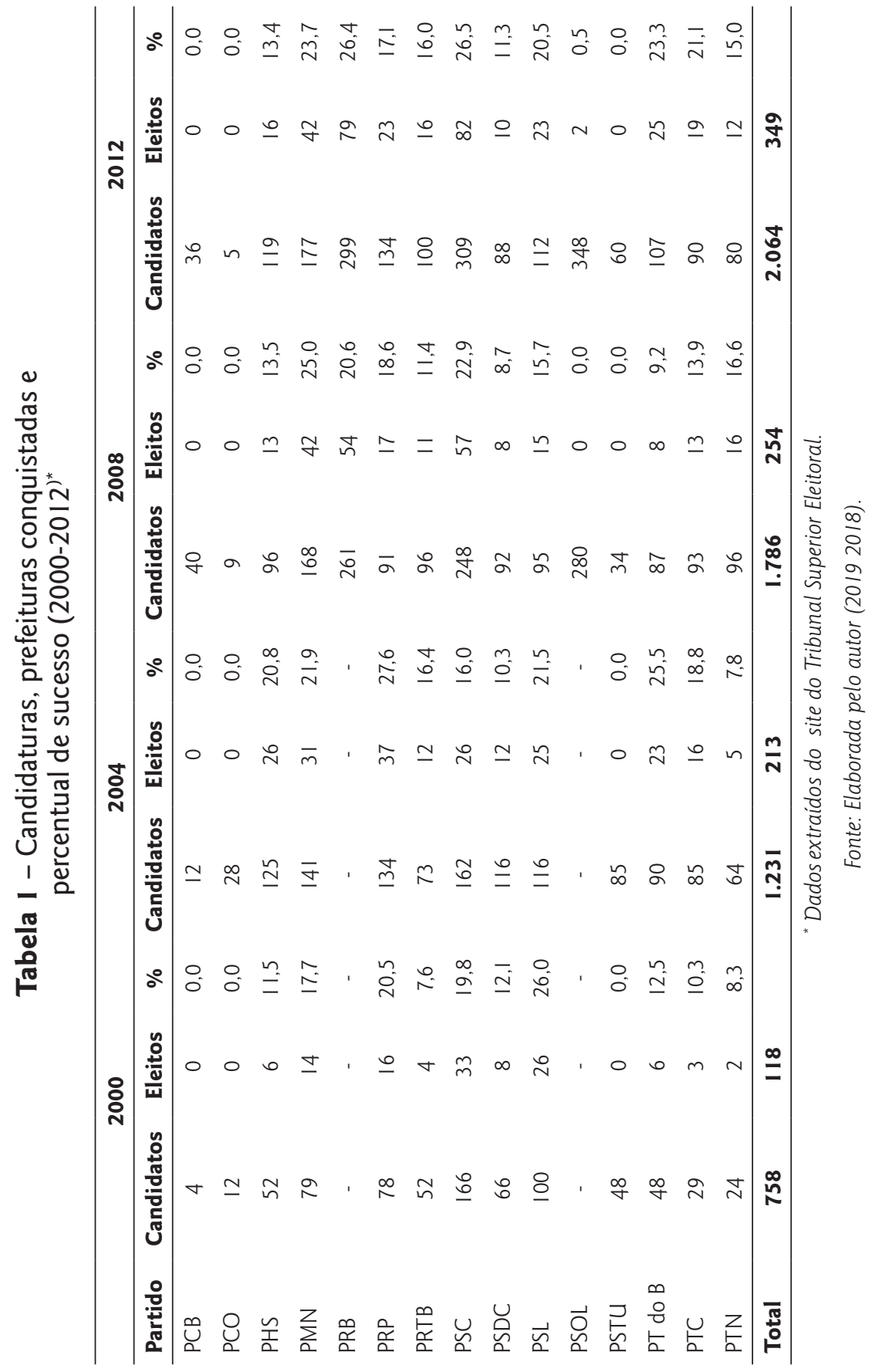


A comparação entre os resultados obtidos nas disputas para o legislativo e executivo municipais evidenciam que o maior desafio, em termos de obtenção de votos, para os pequenos partidos, encontra-se nos pleitos majoritários, nos quais eles têm maiores dificuldades em enfrentar as grandes legendas. Entretanto, este fato não tem sido um impedimento para que tais legendas elejam candidatos para as prefeituras, levando-se em conta as taxas de aproveitamento crescentes e em patamar razoável de algumas delas quando se considera o número de candidaturas lançadas. Trata-se de um dado importante, sobretudo quando se leva em consideração OBSERVA que a ocupação de cargos na esfera municipal serve de plataforma e tem impacto sobre o desempenho de uma legenda nos pleitos estaduais e federal, realizados com diferença de dois anos em relação às eleições locais (MELO, 2013).

Também é possível constatar, no Gráfico 3, que os pequenos partidos têm obtido votaçôes agregadas mais elevadas para os legislativos estaduais nos cinco pleitos analisados, em relação àquelas obtidas nas eleiçôes municipais. Com exceção de três pequenos partidos de esquerda - PCB, PCO e PSTU -, todas as demais legendas superaram pelo menos uma vez o patamar de $1 \%$ do total nacional de votos. Ademais, além de PRB e PSC, que, tal como na arena municipal, são aqueles com melhor desempenho na disputa pelo legislativo, um número maior de legendas foi capaz de aumentar sua votação, casos como o pequeno partido de esquerda PSOL e dos personalistas PRP, PTN e PSL. As curvas de votação dos partidos mostram que o crescimento de alguns deles foi mais acelerado em relação à sua performance nos municípios, além de ser possível ver mais nuances na trajetória, como o caso do PMN, que cresce consideravelmente em 2006, mas náo consegue manter o patamar de votação nas eleiçóes seguintes.

Juntos, os pequenos partidos cresceram em termos de votação para deputados estaduais entre 1998 e 2014, tendo obtido mais de 17\% de todos os votos para as Assembleias Estaduais nesse último pleito, mas essa trajetória não foi constante. Como no caso da disputa para os legislativos municipais, os incrementos no percentual total de votos obtidos variam muito entre os quadriênios. Os pequenos partidos ganharam terreno nas disputas pelo legislativo estadual no período, mas há dois momentos 
distintos. Entre 1998 e 2002, eles mantêm um patamar baixo de votação; em 2006, ocorre um salto no total de votos obtidos, muito em virtude da entrada de dois partidos competitivos no jogo, PRB e PSOL. A partir daí o cenário se estabiliza nas eleiçóes de 2010 e 2014 em torno de $17 \%$.

\section{Gráfico 3 - Votação para Deputado Estadual em todas as UFs (1998-2014)}

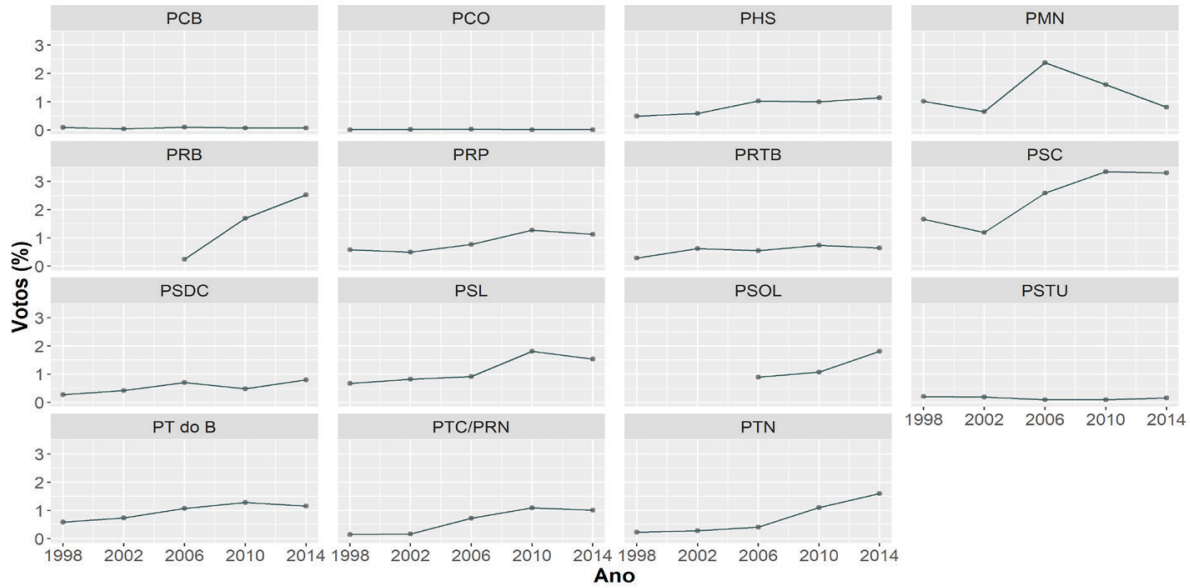

* Dados extraídos do site doTribunal Superior Eleitoral.

Fonte: Elaborado pelo autor (2019 [2018]).

A comparação dos dados do Gráfico 3 com aqueles contidos na Tabela 2 retrata em que medida a votação obtida pelos pequenos partidos políticos resultou na conquista de assentos nos legislativos estaduais. $\mathrm{O}$ aumento de cadeiras obtidas é proporcional ao incremento na votação dos partidos, isto é, a quantidade de deputados que eles elegem em todo o Brasil é muito próxima da proporçáo dos votos que recebem. Além de demonstrar a proporcionalidade do sistema no nível agregado, esse fato sugere que os pequenos partidos não têm se beneficiado das coligaçóes eleitorais para os pleitos estaduais, pois não conseguem eleger uma proporção de candidatos muito superior à sua votação isolada. Os casos excepcionais são o PMN, que obteve $2,08 \%$ dos assentos com 1,63\% dos votos em 2010, e o PRB, que conquistou 3,02\% das cadeiras em disputa com 2,54\% da votação nacional no pleito de 2014 . No total, a proporção de assentos que estes 
partidos ocuparam nas Assembleias Legislativas é, também, proporcional ao total de votos obtidos. Há um aumento expressivo no decorrer do período analisado. Em 1998, o grupo dos pequenos partidos detinha apenas $4,4 \%$ dos assentos nessa arena; e esse número aumentou nas eleiçóes sucessivas, culminando em 17,85\% no pleito de 2014 .

Tabela 2 - Deputados estaduais e distritais eleitos*

\begin{tabular}{|c|c|c|c|c|c|c|c|c|c|c|}
\hline \multirow[b]{2}{*}{ Partido } & \multicolumn{2}{|c|}{1998} & \multicolumn{2}{|c|}{2002} & \multicolumn{2}{|c|}{2006} & \multicolumn{2}{|c|}{2010} & \multicolumn{2}{|c|}{2014} \\
\hline & Eleitos & $\%$ & Eleitos & $\%$ & Eleitos & $\%$ & Eleitos & $\%$ & Eleitos & $\%$ \\
\hline PCB & 0 & 0,00 & 0 & 0,00 & 1 & 0,09 & 0 & 0,00 & 0 & 0,00 \\
\hline PCO & 0 & 0,00 & 0 & 0,00 & 0 & 0,00 & 0 & 0,00 & 0 & 0,00 \\
\hline PHS/PSN & I & 0,09 & 2 & 0,19 & 5 & 0,47 & 7 & 0,66 & 11 & 1,04 \\
\hline PMN & 9 & 0,85 & 9 & 0,85 & 27 & 2,55 & 22 & 2,08 & 8 & 0,76 \\
\hline PRB & - & - & - & - & 3 & 0,28 & 18 & 1,70 & 32 & 3,02 \\
\hline PRP & 3 & 0,28 & 6 & 0,57 & 6 & 0,57 & 13 & 1,23 & 12 & 1,13 \\
\hline PRTB & 2 & 0,19 & 4 & 0,38 & 6 & 0,57 & 10 & 0,94 & 10 & 0,94 \\
\hline PSC & 15 & 1,42 & 13 & 1,23 & 23 & 2,17 & 34 & 3,21 & 35 & 3,31 \\
\hline PSDC & 3 & 0,28 & 6 & 0,57 & 5 & 0,47 & 8 & 0,76 & 9 & 0,85 \\
\hline PSL & 9 & 0,85 & 13 & 1,23 & 7 & 0,66 & 18 & 1,70 & 17 & 1,61 \\
\hline PSOL & - & - & - & - & 2 & 0,19 & 4 & 0,38 & 12 & 1,13 \\
\hline PSTU & 0 & 0,00 & 0 & 0,00 & 0 & 0,00 & 0 & 0,00 & 0 & 0,00 \\
\hline PT do B & 5 & 0,47 & 7 & 0,66 & 14 & 1,32 & 17 & 1,61 & 14 & 1,32 \\
\hline $\begin{array}{l}\text { PTCl } \\
\text { PRN }\end{array}$ & 0 & 0,00 & I & 0,09 & 4 & 0,38 & 8 & 0,76 & 11 & 1,04 \\
\hline PTN & 0 & 0,00 & 3 & 0,28 & 6 & 0,57 & 13 & 1,23 & 18 & 1,70 \\
\hline Total & 47 & 4,44 & 64 & 6,04 & 109 & 10,29 & 172 & 16,24 & 189 & 17,85 \\
\hline
\end{tabular}

* Dados extraidos do site do Tribunal Superior Eleitoral.

Fonte: Elaborada pelo autor (2019 2018).

Os dados agregados nacionalmente não revelam, contudo, um panorama completo do desempenho dos pequenos partidos. Para além do número agregado de cadeiras obtidas, é preciso saber a distribuição delas no território nacional e entender se as conquistas estão dispersas entre as unidades federativas ou se estão concentradas em alguns deles em particular. Os dados da Tabela 3 mostram que há grandes diferenças entre os partidos 
estudados. O PSC se destaca como sendo um partido presente em um bom número de estados desde o início da série; mas, a quantidade de distritos onde consegue eleger candidatos oscila ao longo do tempo. O PRB apresenta uma expansão muito expressiva: em apenas três eleiçóes, o número de unidades da federação onde ganhou cadeiras saltou de três para 18. Os demais partidos personalistas e o PSOL apresentam padrão mais moderado, com presença ainda frágil no território nacional, crescimento discreto e oscilaçôes ao longo do período. Outro dado relevante é que no pleito de 2014 muitos partidos com expansão crescente diminuíram sua presença nos legislativos subnacionais, fruto do impacto dos novos partidos criados após $2012^{5}$. Tais legendas, além de aumentarem a oferta eleitoral e a concorrência com os pequenos partidos, também absorveram alguns de seus quadros, o que teve impacto em sua votação e conquista de cargos.

Outro padrão identificável diz respeito à quantidade de candidatos eleitos em cada UF. Na grande maioria deles, os partidos elegem um ou dois candidatos, sendo relativamente poucos os casos em que um desses partidos logrou obter mais de três cadeiras em uma mesma UF, de modo que o quadro prevalente entre os partidos analisados é de bancadas com um ou dois nomes em cada estado em que obtiveram cadeiras. Outra característica recorrente é o dinamismo com que eles conquistam e perdem cadeiras nos legislativos subnacionais entre um pleito e outro. Com frequência, a derrota e consequente ausência em um estado é compensada com a entrada em outro, de forma que certos partidos conseguem manter sua presença em um número igual ou maior de estados mesmo sofrendo derrotas.

5 Partido Pátria Livre (PPL), Partido Ecológico Nacional (PEN), Partido Republicano da Ordem Social (PROS) e Solidariedade (SD). 
Tabela 3 - Número de estados onde o partido elegeu deputados estaduais/distritais*

\begin{tabular}{lccccc}
\hline Partido & $\mathbf{1 9 9 8}$ & $\mathbf{2 0 0 2}$ & $\mathbf{2 0 0 6}$ & $\mathbf{2 0 1 0}$ & $\mathbf{2 0 1 4}$ \\
\hline PCB & 0 & 0 & 1 & 0 & 0 \\
PCO & 0 & 0 & 0 & 0 & 0 \\
PHS/PSN & 1 & 1 & 5 & 5 & 8 \\
PMN & 5 & 6 & 12 & 15 & 8 \\
PRB & - & - & 3 & 13 & 18 \\
PRP & 2 & 6 & 6 & 9 & 8 \\
PRTB & 1 & 3 & 6 & 8 & 5 \\
PSC & 10 & 9 & 13 & 17 & 15 \\
PSDC & 2 & 4 & 4 & 6 & 6 \\
PSL & 5 & 8 & 7 & 12 & 12 \\
PSOL & - & - & 2 & 3 & 6 \\
PSTU & 0 & 0 & 0 & 0 & 0 \\
PT do B & 4 & 3 & 11 & 15 & 9 \\
PTC/PRN & 0 & 1 & 3 & 7 & 7 \\
PTN & 0 & 2 & 4 & 8 & 10 \\
\hline
\end{tabular}

*Dados extraídos do site do Tribunal Superior Eleitoral. Fonte: Elaborada pelo autor (2019 2018).

Além da quantidade de cadeiras conquistadas nas diversas UFs, a distribuição dessas conquistas nas distintas regiôes é desigual. De modo geral, os pequenos partidos têm maior facilidade em eleger candidatos nos estados do Norte e do Nordeste, onde têm tido presença constante desde o início do intervalo estudado. Com efeito, as primeiras vitórias dos pequenos partidos quase sempre ocorrem em estados da região Norte. A única exceção a este padrão é o PSOL, que elegeu seus primeiros representantes estaduais no Rio de Janeiro e em Sáo Paulo e somente depois se expandiu para os estados do Norte e Nordeste. Os estados do Sudeste, Sul e Centro-Oeste têm sido arenas comparativamente menos permeáveis para os pequenos partidos, visto que elegem pequenas bancadas e não mantêm grande constância. Em que pese o desempenho obtido pelo PSC no Paraná 
em $2014^{6}$, a região Sul se apresenta como a mais difícil para eles, com apenas três representantes eleitos no Rio Grande do Sul e nenhum em Santa Catarina. No Sudeste, os pequenos partidos conseguem aceder aos legislativos com maior ênfase somente a partir de 2006, o mesmo ocorrendo nos estados do Centro-Oeste.

Nas eleições gerais, os deputados federais também são eleitos por seus respectivos estados e Distrito Federal, competindo, portanto, na mesma arena dos candidatos aos legislativos estaduais. A estratégia de vincular as candidaturas nos dois níveis, prática conhecida como dobradinha, é comum e frequente no Brasil, e pretende aumentar as chances de vitória de ambos os candidatos vinculados. Assim, dois candidatos, um em cada nível, além de pedirem votos para si, orientam seus eleitores a escolher seu aliado, que compete no outro nível. Com a possibilidade de realizar coalizóes eleitorais, não raramente a dobradinha é praticada entre candidatos de partidos distintos pertencentes a uma mesma coligaçáo.

\section{Gráfico 4 - Votação para Deputado Federal (1998-2014)*}

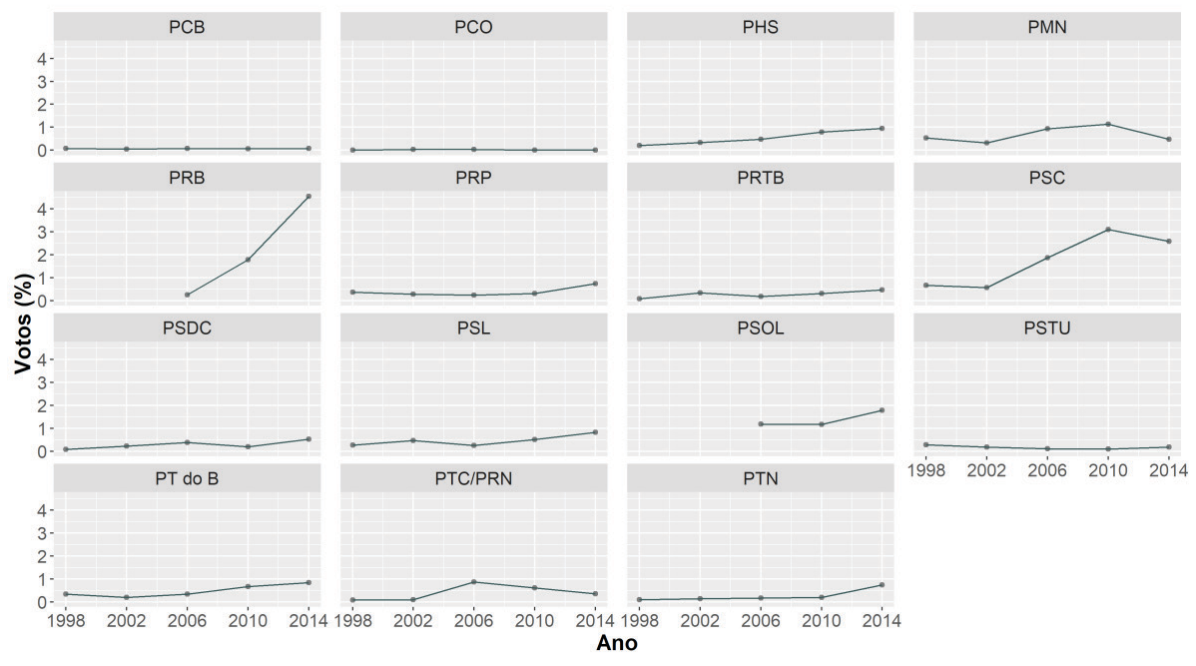

*Dados extraídos do site do Tribunal Superior Eleitoral.

Fonte: Elaborado pelo autor (2019 2018).

6 O PSC elegeu 12 deputados para a Assembleia Legislativa do Estado neste pleito. 
O Gráfico 4 mostra que, de fato, os pequenos partidos têm obtido uma proporção de votos para o pleito nacional semelhante àquela verificada no nível estadual. De maneira análoga ao que se verificou nas eleiçóes para outros níveis da federação, apenas três pequenos partidos demonstraram ter capacidade de expandir sua votação durante o período analisado. $\mathrm{PRB}, \mathrm{PSC}$ e PSOL são os únicos partidos que superam a barreira de $1 \%$ de votos agregados nacionalmente e cuja curva tem trajetória ascendente. No caso do PRB, a ascensão é bastante expressiva, já que, no intervalo de três eleiçóes, o partido aumentou em 1712\% sua votação e superou o PSC, este que até o pleito de 2010 era o pequeno partido mais exitoso nessa arena. Os demais partidos possuem votação baixa, inferior ou igual a $1 \%$ do total nacional ao longo do período, com pequenas oscilaçóes nos casos do PMN e do PT do B.

O panorama que emerge dos dados relativos à disputa pela câmara baixa do Congresso aponta que o nível federal é um desafio maior para os pequenos partidos. Além dos três pequenos partidos de esquerda cuja capacidade de conquista de votos permaneceu baixa em todos os níveis, também os pequenos partidos personalistas e um confessional, o PSDC, apresentam performance praticamente irrisória em pleitos para esta esfera. Do ponto de vista agregado, contudo, o grupo de pequenos partidos analisados aumentou consideravelmente o apoio que recebe em pleitos para a Câmara dos Deputados. Nas eleiçóes de 1998 eles respondiam, juntos, por apenas 3,11\% do total de votos para Deputado Federal. Nos pleitos seguintes, esta parcela aumentou paulatinamente para 3,74\% em 2002, 7,37\% nas eleiçóes de 2006, 10,98\% no pleito de 2010 e, finalmente, atingiu 15,13\% em 2014. Este crescimento, em termos de votos, foi, em boa medida, traduzido em presença na Câmara, conforme é possível ver na Tabela 4. 
Tabela 4 - Deputados federais eleitos e percentual de cadeiras $(1998-2014)^{*}$

\begin{tabular}{|c|c|c|c|c|c|c|c|c|c|c|}
\hline \multirow[b]{2}{*}{ Partido } & \multicolumn{2}{|c|}{1998} & \multicolumn{2}{|c|}{2002} & \multicolumn{2}{|c|}{2006} & \multicolumn{2}{|c|}{2010} & \multicolumn{2}{|c|}{2014} \\
\hline & Eleitos & $\%$ & Eleitos & $\%$ & Eleitos & $\%$ & Eleitos & $\%$ & Eleitos & $\%$ \\
\hline PCB & 0 & 0,00 & 0 & 0,00 & 0 & 0,00 & 0 & 0,00 & 0 & 0,00 \\
\hline PCO & 0 & 0,00 & 0 & 0,00 & 0 & 0,00 & 0 & 0,00 & 0 & 0,00 \\
\hline PHS/PSN & 0 & 0,00 & 0 & 0,00 & 2 & 0,39 & 2 & 0,39 & 5 & 0,97 \\
\hline PMN & 2 & 0,39 & 1 & 0,19 & 3 & 0,58 & 4 & 0,78 & 3 & 0,58 \\
\hline PRB & - & - & - & - & 1 & 0,19 & 8 & 1,56 & 21 & 4,09 \\
\hline PRP & 0 & 0,00 & 0 & 0,00 & 0 & 0,00 & 2 & 0,39 & 3 & 0,58 \\
\hline PRTB & 0 & 0,00 & 0 & 0,00 & 0 & 0,00 & 2 & 0,39 & 1 & 0,19 \\
\hline PSC & 2 & 0,39 & 1 & 0,19 & 9 & ।,75 & 17 & 3,31 & 13 & 2,53 \\
\hline PSDC & 0 & 0,00 & 1 & 0,19 & 0 & 0,00 & 0 & 0,00 & 2 & 0,39 \\
\hline PSL & I & 0,19 & 1 & 0,19 & 0 & 0,00 & I & 0,19 & 1 & 0,19 \\
\hline PSOL & - & - & - & - & 3 & 0,58 & 3 & 0,58 & 5 & 0,97 \\
\hline PSTU & 0 & 0,00 & 0 & 0,00 & 0 & 0,00 & 0 & 0,00 & 0 & 0,00 \\
\hline PT do B & 0 & 0,00 & 0 & 0,00 & 1 & 0,19 & 4 & 0,78 & 2 & 0,39 \\
\hline \multicolumn{11}{|l|}{ PTCl } \\
\hline PRN & 0 & 0,00 & 0 & 0,00 & 3 & 0,58 & I & 0,19 & 2 & 0,39 \\
\hline PTN & 0 & 0,00 & 0 & 0,00 & 0 & 0,00 & 0 & 0,00 & 4 & 0,78 \\
\hline Total & 5 & 0,97 & 4 & 0,78 & 22 & 4,29 & 44 & 8,58 & 62 & 12,09 \\
\hline
\end{tabular}

*Dados extraídos do site do Tribunal Superior Eleitoral.

Fonte: Elaborada pelo autor (2019 2018).

Ao longo do período incluído neste estudo, os únicos pequenos partidos que não foram capazes de eleger nenhum candidato para a Câmara dos Deputados pertencem ao grupo de legendas de esquerda - PCB, PCO e PSTU. As demais lograram ocupar cadeiras na Casa em pelo menos uma ocasião. Destas, quatro - PMN, PRB, PSC e PSOL - nunca deixaram de eleger pelo menos um representante para o legislativo federal. Os percentuais de candidatos eleitos são muito semelhantes aos votos obtidos nacionalmente pelas legendas, ilustrando a alta proporcionalidade do sistema brasileiro. A única exceção parcial é o PSOL, que obteve sempre proporçóes menores de cadeiras em relação à proporção nacional de votos. Em geral, o aumento no número de cadeiras conquistadas também refletiu o crescimento que esses partidos obtiveram em suas votaçóes. Em 1998, os 
pequenos partidos ocupavam apenas cinco assentos na Casa, ou seja, pouco menos de 1\%. Já em 2014, esta quantidade saltou para 62 cadeiras, ou $12,09 \%$. Para efeitos de comparação, se fossem um só partido, os pequenos teriam a terceira maior bancada da legislatura 2015-2018, atrás apenas do PT, com 70, e do PMDB, com 66 assentos. A comparaçáo aponta que alguns desses pequenos partidos podem, em vista de seu crescimento na Câmara, tornar-se atores relevantes para o jogo político e para as negociaçôes de governo. É o caso de PRB e PSC, em particular, visto que, na referida legislatura, chegaram a ter presidentes de comissóes na casa.

Nas eleições majoritárias nos níveis estadual e federal, os pequenos partidos têm apresentado uma atuação muito incipiente. Com exceção dos pequenos partidos de esquerda que lançam com frequência candidatos ao Senado, Governos Estaduais e à Presidência, com o objetivo de realizar propaganda de cunho ideológico, os demais partidos competem para estes cargos apenas ocasionalmente e com desempenhos, em geral, muito modestos. Alguns partidos merecem destaque nessa perspectiva: PMN e PSL elegeram um governador, cada, nos estados do Amazonas e de Roraima em 2010 e 2002, respectivamente. Em ambos os casos, os candidatos eleitos eram políticos conhecidos em seus estados - tendo ocupado as prefeituras de suas capitais antes de se tornarem governadores - e utilizaram as siglas como veículo eleitoral, abandonando-as no curso do mandato.

PSOL e PSC, por sua vez, elegeram um Senador cada em 2010, enquanto o PRTB fez o mesmo em 2006. Nos dois primeiros casos, os candidatos eleitos, Randolfe Rodrigues e Eduardo Amorim, já haviam sido deputados em seus estados por partidos maiores (PT e DEM, respectivamente). No caso do PRTB, trata-se de Fernando Collor, figura de grande capital político em seu estado, além de ter sido deputado federal, governador e presidente da república. Em termos de candidaturas para a presidência da República, somente o PSOL foi capaz de receber uma votação expressiva no período analisado, ainda que não tenham faltado candidatos concorrendo pelos pequenos partidos. Ainda assim, o partido apenas se saiu bem em sua primeira eleição, quando Heloísa Helena recebeu 6,85\% dos votos. Em 2010, o PSOL lançou Plínio de Arruda Sampaio à presidência e obteve votação de 0,87\%, enquanto em 2014 disputou com Luciana 
Genro, recebendo $1,55 \%$ dos votos. De todos os partidos analisados, somente PRB e PTC não lançaram candidatos ao cargo máximo e nenhum deles recebeu mais de $1 \%$ dos votos.

O quadro que emerge da análise das trajetórias eleitorais dos pequenos partidos mostra que eles náo podem ser tomados como um grupo homogêneo no que tange à sua capacidade de obtenção de apoio eleitoral. Nesse sentido, a categoria tipológica proposta para sua análise, que os divide em três grupos - esquerda, personalistas e confessionais - É ÚTIL para identificar os motivos destas diferenças. Os partidos que mais se destacam, tendo expandido consideravelmente sua votação para o legislativo em todos os níveis da federação e também para os executivos municipais, são os confessionais $\mathrm{PRB}$ e PSC, que se tornaram atores relevantes no cenário político nacional. O outro partido que se destaca é o PSOL, de esquerda, que, apesar de ter desempenho inferior aos dois primeiros em termos de votos e cargos, apresentou trajetória ascendente superior aos demais partidos tanto de esquerda quanto personalistas. As legendas pertencentes a este último grupo, por sua vez, têm trajetória homogênea e estável de obtenção de votos e cargos, abaixo dos três partidos de melhor desempenho, porém melhor do que as demais legendas de esquerda. A performance do PSDC é semelhante à deste grupo de legendas, de modo que é a única expoente do grupo de confessionais que não logra expandir o apoio obtido de maneira mais expressiva. Por fim, os demais pequenos partidos de esquerda mantêm uma trajetória bastante esquálida ao longo do período analisado em todos os níveis e estes atores não obtêm acesso de forma relevante a cargos eletivos.

As razóes para essas dinâmicas exclusivas podem ser buscadas nos fatores que diferenciam estes partidos entre si. $\mathrm{O}$ desempenho dos partidos políticos decorre de seus objetivos como organizaçóes, das estratégias adotadas (ambos os aspectos influenciados pela dimensão ideológico-programática) e de sua capacidade efetiva de perseguir tais objetivos e implementar as estratégias definidas (o que diz respeito à dimensão organizacional). Nas próximas seçôes, serão analisadas estas duas dimensôes, com foco nas distinçôes entre os três grupos distintos para obter uma melhor compreensão de suas trajetórias eleitorais. 


\section{Objetivos e estratégias dos pequenos partidos}

A distinção mais marcante entre as legendas aqui analisadas se encontra nos perfis ideológicos que elas apresentam, podendo ser agrupadas em três categorias: partidos de esquerda de inspiraçáo leninista, partidos personalistas e partidos confessionais. Uma das implicaçóes mais profundas destas distinçóes diz respeito à definição dos objetivos que o partido irá perseguir. Trata-se de uma decisão crucial na trajetória da organizaçáo e em geral está vinculada ao momento de sua gênese, quando se definem os eixos em torno dos quais ela se estruturará e atuará. Estes objetivos guardam estreita relação com a ideologia, pois ela é a responsável por fornecer aos membros e simpatizantes do partido aquilo que Panebianco (2005) denomina como a "causa comum" que motiva a existência da legenda.

Dentre os partidos analisados, há uma grande variação na centralidade do aspecto ideológico para a organização. As pequenas legendas de esquerda são aquelas que dão maior ênfase às mensagens ideológicas e onde esse aspecto mais influi nas decisóes, estratégias e na própria organização ${ }^{7}$. Disso decorre que, para eles, a função do partido não reside na obtenção de cargos públicos per se, mas antes na transformação do atual modelo de sociedade visando a efetivar a causa pela qual o partido luta; neste caso, trata-se da causa proletária ou socialista, o que pressupóe buscar profundas mudanças na estrutura social e econômica do país. Diante disso, a competição eleitoral ganha um significado estratégico de veículo para a divulgação da mensagem do partido, isto é, passa a ser vista como um meio de disseminação dos ideais e da doutrina do partido. Isso explica, em parte, a insistência dessas legendas em lançarem candidatos aos cargos executivos e, particularmente, à presidência. São eles que garantem maior visibilidade à mensagem do partido. Essa perspectiva ajuda a entender também a persistência dessas organizaçóes ao longo do tempo. Uma análise que pretendesse enquadrá-las na premissa segundo a qual partidos são maximizadores de votos (DOWNS, 1999) não conseguiria explicar por que insistir por tanto tempo diante de táo baixo retorno em termos de votos.

7 PCB, PCO e PSTU trazem em seus estatutos menções ao conceito de centralismo democrático formulado por Lênin ( 1902) como um princípio segundo o qual estes partidos se organizam funcionam. 
Outro aspecto estratégico que decorre de sua ideologia é o pequeno número de coligaçóes eleitorais que realizam. Dantas e Praça (2010), ao analisarem as coligaçóes dos pequenos partidos nas eleiçóes municipais entre 2000 e 2008, constatam que os pequenos partidos de esquerda sáo os que realizam o menor número de coligaçóes nos pleitos estudados, mas que há grande diferença no percentual de coligaçóes entre eles. No caso do PCB, o percentual de municípios com coligaçóes ultrapassa os $90 \%$ em duas eleiçóes. Já PCO nunca realizou coligaçóes em mais de $30 \%$ dos municípios onde concorreu no período, e o PSTU oscila entre 4\% e 60\%, sem demonstrar algum padrão.

O PSOL, embora também de esquerda, apresenta um padrão muito diferente, com um patamar de votação mais próximo aos demais partidos competitivos. Embora ele adote uma política de coligaçóes igualmente restrita nos pleitos em que concorre, aliando-se somente a outros pequenos partidos de esquerda, ele possui duas características que o distinguem dos demais: i) sua origem parlamentar lhe garantiu membros com algum capital político-eleitoral já consolidado, bem como uma orientação mais vote-seeking:; ii) sua variante ideológica é muito mais calcada no eurocomunismo do que nas correntes mais ortodoxas leninistas e trotskistas que orientam as demais legendas de esquerda. Não se trata, portanto, de um partido "revolucionário", interessado apenas em utilizar taticamente as eleiçóes para efeito de propaganda. O PSOL quer crescer por dentro da democracia representativa. Ele é um partido "desafiante", porém sistêmico. Sua situação corresponde ao quadro descrito por Downs (1999):, isto é, quando um partido que domina um dos polos do espectro ideológico se move em direção ao centro para ampliar seu eleitorado, outros partidos surgem para ocupar o espaço deixado por ele e disputar seu antigo eleitorado. Esse é o caso do PSOL, que disputa o eleitorado de esquerda do PT.

Os partidos confessionais concedem comparativamente menor centralidade à sua ideologia, ainda que ela permeie as mensagens de seus membros e candidatos em suas manifestações individuais. Uma razão da relativa moderaçáo por parte dessas legendas decorre do fato que elas reúnem

8 Perfil tipológico de partidos orientados principalmente para a maximização de votos. 
membros de vertentes diferentes do cristianismo e, portanto, procuram se ater aos aspectos comuns a elas.

Um posicionamento diferente é aquele de seus membros, em particular dos que detêm mandados eletivos, alguns dos quais têm se destacado pela defesa de dogmas e princípios conservadores do cristianismo e tentado promover políticas públicas baseadas neles. Se os partidos de esquerda almejam a transformação radical da sociedade, os confessionais visam à manutenção de uma série de políticas e normas com as quais se identificam em virtude de seus valores religiosos, tais como a proibição do aborto, do casamento entre pessoas do mesmo sexo, da pesquisa com células-tronco embrionárias, dentre outras. Sua estratégia visa, justamente, a ocupar os cargos e posiçóes que lhes permitam atuar para a promoção desses objetivos, de sorte que a conquista de votos e cargos é crucial para eles. Portanto, os partidos confessionais têm muitos incentivos para adotar estratégias que lhes permitam expandir sua votação e suas bancadas, pois é, por meio delas, que eles têm condiçóes de promover sua causa.

Eles frequentemente realizam coligaçóes e não tendem a ser muito seletivos em termos dos partidos maiores com os quais se associam nas eleiçóes. Conferem ligeira preferência aos grandes partidos de direita, de cujas agendas e posiçôes são mais afins, mas também se coligam com frequência quase igual a legendas de centro e de esquerda (DANTAS; PRAÇA, 2010), o que revela seu pragmatismo voltado para a maximização de suas chances. Outra estratégia muito frequente é o uso dos títulos religiosos por seus candidatos, tais como pastor, bispo, ou ministro, como forma de aumentar sua interlocução com parcelas do eleitorado de determinados segmentos religiosos. Com frequência os slogans utilizados nas campanhas também contêm mensagens de cunho religioso.

Essa conduta tem sido parcialmente responsável pela ascensão de PSC e PRB nos últimos pleitos, mas não tem surtido o mesmo efeito para PSDC, cujo desempenho eleitoral está muito abaixo de seus congêneres. Uma explicação possível para esse fato decorre dos fortes vínculos que PSC e PRB possuem com instituições religiosas evangélicas, em particular a Assembleia de Deus e a Igreja Universal do Reino de Deus, respectivamente. Essas organizaçóes funcionam, muitas vezes, como verdadeiras instituiçóes 
informais destes dois partidos. Freidenberg e Levitsky (2006) apontam que muitos dos partidos latino-americanos parecem organizaçôes fracamente institucionalizadas quando se analisa sua estrutura formal, isto é, aqueles órgãos que integram a estrutura legalmente reconhecida dos partidos, mas muitas vezes possuem vastas redes "informais" de vínculos com instituiçôes que atuam em outras esferas sociais. Este parece ser o caso destas duas legendas. Muitos de seus membros e candidatos são vinculados a essas duas instituições religiosas, alguns inclusive na condição de sacerdotes, de modo que sua atuação política e religiosa converge e eles dispóem de um importante "palanque informal" nos templos e nos demais locais de culto religioso. Isto lhes garante exposição para além do período das candidaturas políticas, pois, dada a natureza perene das atividades religiosas, os membros de partido que nelas atuam continuam em evidência na condição de sacerdotes ou lideranças na comunidade de fiéis. O PSDC, por ser vinculado à Igreja Católica, tem, em tese, menor espaço para que seus membros se aproveitem de seus vínculos para fins eleitorais. Isto se dá, em primeiro lugar, porque existe a proibição de que os sacerdotes católicos disputem cargos políticos e, em segundo, porque os católicos não constituem comunidades de vínculos tão fortes quanto os evangélicos.

Essa distinção é corroborada pelos dados da pesquisa "Trajetórias, Perfis e Padrôes de Interação de Legisladores em Doze Unidades da Federação", realizada pelo Centro de Estudos Legislativos da Universidade Federal de Minas Gerais (UFMG) ${ }^{9}$. Uma das questôes perguntava ao deputado se ele recebeu algum apoio de sua Igreja ou denominaçáo religiosa. A Tabela 5 traz os dados das respostas obtidas nas duas rodadas dessa pesquisa. É possível notar que um percentual muito superior de deputados evangélicos declarou receber apoio de suas instituiçóes religiosas em relaçáo aos deputados que professam outras religióes. A comparaçáo com os católicos é especialmente relevante: enquanto quase dois terços dos evangélicos ouvidos declararam ter recebido apoio das instituiçóes religiosas das quais participam, somente um quarto dos católicos foi apoiado por suas

9 A pesquisa entrevistou os deputados estaduais nas Assembleias de 12 estados brasileiros: três no Sudeste (SP, MG, RJ), dois no Sul (RS e PR), três no Nordeste (PE, BA e CE), dois no Centro-Oeste (GO e MT) e dois no Norte (PA e TO), em duas legislaturas 2007-2010 e 20II-20I4. 
igrejas. Considerando os vínculos que PSC e PRB possuem com instituições evangélicas, esse dado é central para a compreensão da evolução de seu desempenho eleitoral e de seu sucesso relativamente aos demais pequenos partidos.

Pequenos partidos personalistas posicionam-se no extremo oposto aos partidos de esquerda em termos da importância dada à ideologia. Em certa medida, é possível afirmar que tais partidos não possuem um conteúdo ideológico-programático bem definido e adotam aquilo que Baquero e Vasconcelos (2013) apontam como "ideologia híbrida"; isto é, um perfil que não "catalisa identidades coletivas fortes".

Tabela 5 - Percentual de deputados estaduais que recebem apoio de suas igrejas ou denominações ${ }^{*}$

\begin{tabular}{|c|c|c|c|c|c|}
\hline & & & \multicolumn{2}{|c|}{$\begin{array}{l}\text { Para estar na política tem apoio } \\
\text { de sua igreja ou denominação? }\end{array}$} & \multirow[b]{2}{*}{ Total } \\
\hline & & & Sim & Não & \\
\hline \multirow{8}{*}{ Religião do Deputado } & \multirow{2}{*}{ Católica } & $\mathrm{N}$ & 168 & 524 & 692 \\
\hline & & $\%$ & $24,30 \%$ & $75,70 \%$ & $100 \%$ \\
\hline & \multirow{2}{*}{ Evangélica } & $\mathrm{N}$ & 80 & 42 & 122 \\
\hline & & $\%$ & $65,60 \%$ & $34,40 \%$ & $100 \%$ \\
\hline & \multirow{2}{*}{ Espírita } & $\mathrm{N}$ & 0 & 20 & 20 \\
\hline & & $\%$ & $0 \%$ & $100 \%$ & $100 \%$ \\
\hline & \multirow{2}{*}{ Outra } & $\mathrm{N}$ & 3 & 15 & 18 \\
\hline & & $\%$ & $16,70 \%$ & $83,30 \%$ & $100 \%$ \\
\hline \multirow{2}{*}{ Total } & & $\mathbf{N}$ & 251 & 601 & 852 \\
\hline & & $\%$ & $29,50 \%$ & $70,50 \%$ & $100 \%$ \\
\hline
\end{tabular}

*Dados extraídos do Centro de Estudos Legislativos da Universidade Federal de Minas Gerais. Fonte: Elaborada pelo autor (2019).

Sendo personalistas, estas legendas contam com o carisma e o capital político de suas lideranças como principal meio para obter apoio eleitoral. Nesse sentido, suas campanhas são focadas na personalidade de seus membros com mensagens destinadas a exaltar qualidades genéricas de seus candidatos. $\mathrm{O}$ foco dos partidos personalistas não é necessariamente expandir seu eleitorado e obter um amplo apoio da sociedade, tampouco 
promover determinadas causas ou políticas. Sua orientação primária é por cargos. Portanto, a competição política é encarada apenas como um meio de garantir que suas lideranças obtenham acesso aos postos na estrutura estatal, pela via eleitoral ou ocupando cargos por indicaçáo política. Assim, sua meta eleitoral primária é obter os votos necessários para eleger uma quantidade de candidatos que garanta algum poder de barganha após a eleição junto aos partidos maiores. Isso se traduz em um comportamento bastante pragmático no que se refere à realização de coligaçóes eleitorais privilegiando aquelas que aumentem suas chances de obter cadeiras nas disputas legislativas.

Quando lançam campanhas para cargos no executivo, em especial para a Presidência da República, estas legendas se apresentam sempre com o mesmo candidato que, com frequência, é também seu presidente e fundador. Ainda que tenham desempenho insignificante no pleito nacional, tal estratégia lhes garante visibilidade e, sobretudo, a possibilidade de inserir a legenda entre os grandes partidos a fim de fazer acordos futuros com estes, negociando seu apoio aos candidatos que disputam o segundo turno e aos vencedores. $\mathrm{O}$ desempenho mediano que apresentam nos dados analisados é reflexo de seu foco na obtenção de cargos para suas lideranças. Uma vez garantido o acesso a um mínimo de cargos, não há grandes incentivos para que o partido se expanda. A persistência de alguns partidos no pleito para o Executivo nacional, a despeito do baixo patamar recorrente de votos obtidos por eles, é sintomática do domínio que essas personalidades têm sobre a legenda. Essa persistência é ilustrada pela recorrência na apresentação dos mesmos candidatos, como é o caso do PRTB com Levy Fidelix, ou do PSDC com Eymael. Muito mais do que entidades orgânicas com certo nível de interação sistêmica entre seus membros, os partidos personalistas são plataformas para projeção de carreiras políticas. Melo (2004), analisando a migração partidária entre 1985 e 2001, mostra que os pequenos partidos são aqueles que apresentam taxas mais altas de deserçóes. No caso dos partidos personalistas, denominados pelo autor como pequenos partidos de direita, a proporçáo de abandono chegou a 60\% dos deputados entre 1985 e 2001, tendência esta que se mantem até os dias de hoje. Verificase um padrão no qual os candidatos utilizam a legenda para se elegerem e a abandonam após a posse, de modo que somente a principal liderança 
permanece no partido. Isso demonstra o problema de institucionalização destas legendas, que não chegam a se tornar "fins em si mesmos", conforme previra Panebianco (2005), a propósito do processo de institucionalização, e permanecem como constelaçóes de políticos agindo de forma autônoma sem grandes vínculos organizacionais.

\section{Estrutura e máquina eleitoral}

Grande parte das dificuldades enfrentadas pelos pequenos partidos políticos se deve à incipiência de suas máquinas eleitorais. Para conseguir disputar eleiçôes, um partido deve dispor de bases organizacionais que lhe permitam atuar de acordo com a escala em que os pleitos ocorrem. No caso brasileiro, isso significa estar presente no maior número de municípios possível, pois os diretórios municipais são a dimensão mais elementar dos partidos brasileiros ${ }^{10}$. É na arena municipal que os partidos se encontram mais próximos da sociedade e, sobretudo, é a partir dela que mobilizam eleitores e militantes, e que recrutam as lideranças e os candidatos.

Melo (2013), ao analisar o PMDB, ressalta a existência de uma correlação entre as votaçóes das prefeituras comandadas pelo partido e a origem dos votos que este conquista para a Câmara dos Deputados, e afirma que o nível municipal é a dimensão-chave para o desempenho dos partidos nos demais pleitos no país.

Presumimos que as eleições municipais são a porta de entrada dos partidos no jogo eleitoral. As disputas para os cargos estaduais e federais são organizadas a partir das bases municipais e, nesse sentido, quanto mais apoio os partidos e candidatos conseguirem nos municípios, maior a probabilidade de terem êxito nas outras esferas. (MELO, 2013, p. 18-19).

Segundo o autor, a construção de uma rede de organizaçóes municipais nos estados parece ter sido o segredo do PMDB para se fortalecer e consolidar como um dos partidos mais fortes no período da Nova República. É nos municípios que o partido angaria votos que o fortalecem na dimensão local, a partir da qual ele se projeta nos níveis estaduais e federal. É razoável supor que essa dinâmica não seja apenas uma particularidade

10 Exceção feita aos pequenos partidos de esquerda que se organizam em células partidárias como elemento mais básico de sua estrutura. 
do PMDB, mas uma espécie de regra para a sobrevivência e consolidação dos partidos no Brasil. Dessa forma, um aspecto central para os pequenos partidos é a sua expansão e radicação no território nacional. Isto é, se seguirmos a definição segundo a qual partidos são agentes maximizadores de votos, o grande desafio das pequenas legendas brasileiras consiste em expandir tanto quanto possível sua presença nos municípios brasileiros. Isso lhes daria, ao longo do tempo, o acúmulo de capital humano e político necessário para se tornarem competitivos.

De acordo com Panebianco (2005), a expansão territorial de um partido pode ocorrer essencialmente de duas formas: por penetração ou difusão. O primeiro caso ocorre quando um "centro decisório" controla, estimula e dirige o desenvolvimento da "periferia", isto é, a formação das instâncias locais e intermediárias do partido. $\mathrm{O}$ segundo ocorre em contextos nos quais o desenvolvimento se dá por "germinação espontânea", visto que as elites locais se reúnem e constroem associaçôes partidárias que somente depois são aglutinadas no nível nacional. Ainda segundo o autor, os partidos tenderão a apresentar ambas as formas de expansão, mas uma será predominante sobre a outra (PANEBIANCO, 2005). Legendas que se desenvolvem por difusão têm seu processo de formação de lideranças mais tormentoso e complexo devido à existência de núcleos consideráveis de líderes locais. E estes, que surgiram de maneira autônoma, controlam suas próprias instâncias partidárias locais e, portanto, podem aspirar à liderança nacional do partido. Por outro lado, legendas onde predomina a penetração tendem a ser muito mais coesas e manejáveis, pois o protagonismo do "centro" tende a garantir o controle da instância nacional sobre a local, o que se traduz em maior margem de manobra por parte da primeira em face da segunda.

No Brasil, a literatura tem voltado sua atenção para esta dimensão das agremiaçôes partidárias. Braga e Silveira (2012) analisam a presença territorial de todos os partidos brasileiros a partir de dados do TSE coletados em 2011. O estudo aponta uma diferença no perfil de expansão das bases locais entre há partidos grandes e médios de um lado, e os pequenos, de outro. Enquanto os do primeiro grupo tiveram uma expansão da cobertura territorial mais rápida que a expansão no número de filiados, os demais apresentam uma trajetória quase linear em que a expansão territorial e o aumento do número de filiados avançam pari passu. 
Isso evidencia a forte dependência de trajetória dos elementos que separam partidos grandes e médios dos partidos pequenos. Ademais, o estudo aponta a existência de grandes diferenças organizacionais entre esses partidos. Os grandes tendem a ser mais descentralizados e consolidados, ao passo que os pequenos partidos são mais centralizados e menos institucionalizados. Na mesma linha, Guarnieri (2011) chama atenção para a "fraqueza” organizacional dos partidos brasileiros. Ele analisa a proporção de comissóes provisórias municipais (CPs) por diretórios municipais das principais legendas e revela que a maioria prefere manter as precárias comissóes a institucionalizá-las em diretórios. Isso garante aos dirigentes partidários nacionais um grande controle sobre os braços locais de suas legendas. Perspectiva que vai ao encontro do que afirma Rodrigues (1995, p. 89):

As implicações disto [o elevado número de comissões provisórias] para o controle partidário são claras: como são os dirigentes partidários que controlam as comissões provisórias, são eles também que escolhem os delegados às convenções. Quando comissões provisórias formam parte significativa dos órgãos partidários, esses dirigentes possuem grande controle sobre as convenções, pois controlam parte significativa dos votos.

Para além do controle dos votos, as comissôes provisórias são também mais facilmente manipuláveis, pois os diretórios estaduais ou nacionais podem, caso queiram, nomear interventores ou mesmo dissolvê-las. Assim, a proporção de comissóes provisórias por diretórios é um bom indicador do grau de fragilidade organizacional de um partido e do quão centralizado é o seu processo decisório interno. A Tabela 6 mostra a quantidade de organizaçóes que os pequenos partidos analisados possuíam no âmbito municipal, identificando o número de comissóes provisórias e interventoras e o número de diretórios. Os dados são referentes ao mês de maio de 2014. Os dados da tabela explicitam as diferenças entre os pequenos partidos do ponto de vista organizacional. 
Tabela 6 - Organização territorial dos pequenos partidos brasileiros $-2014^{*}$

\begin{tabular}{lcccc}
\hline Partido & CPs+Cls $^{* *}$ & Diretórios & Total & Percentual de CPs+Cls \\
\hline PCB & 105 & 2 & 107 & 98,1 \\
PCO & 31 & 12 & 43 & 72,1 \\
PHS/PSN & 883 & 170 & 1.053 & 83,9 \\
PMN & 1.458 & 19 & 1.477 & 98,7 \\
PRB & 2.891 & 6 & 2.897 & 99,8 \\
PRP & 1.567 & 42 & 1.609 & 97,4 \\
PRTB & 607 & 7 & 614 & 98,9 \\
PSC & 3.003 & 252 & 3.255 & 92,3 \\
PSDC & 380 & 111 & 491 & 77,4 \\
PSL & 1.140 & 214 & 1.354 & 84,2 \\
PSOL & 423 & 133 & 556 & 76,1 \\
PSTU & 18 & 70 & 88 & 20,5 \\
PT do B & 1.615 & 152 & 1.767 & 91,4 \\
PTC/PRN & 826 & 26 & 852 & 96,9 \\
PTN & 1.502 & 17 & 1.519 & 98,9 \\
\hline Total & $\mathbf{1 . 6 4 4 9}$ & $\mathbf{1 . 2 3 3}$ & $\mathbf{1 7 . 6 8 2}$ & \\
\hline & $15905 x$ & & &
\end{tabular}

*Dados extraídos do Tribunal Superior Eleitoral.

** Somatório de comissões provisórias e comissões interventoras.

Fonte: Elaborada pelo autor (2019).

É possível perceber que as legendas que apresentam melhor desempenho eleitoral - PRB e PSC - são também aquelas que possuem maior densidade organizacional nos municípios, quer sejam diretórios, quer sejam comissôes provisórias/interventoras; ademais, elas são as duas únicas legendas do grupo estudado presentes em mais da metade dos municípios brasileiros. Há que se ressaltar, no entanto, que essa não é uma relação automática, isto é, o crescimento eleitoral não é diretamente vinculado à presença do partido em um número maior de municípios. Alguns partidos personalistas, como PT do B, PRP e PMN, apresentam capilaridade comparativamente alta em relação às demais legendas. No entanto, essa diferença não se traduziu em um desempenho melhor. Por outro lado, o PSOL se tornou tão 
ou mais competitivo nas arenas estadual e federal mesmo com um número relativamente baixo de órgãos. Isso sugere que a capilaridade no território nacional é uma condição necessária; porém, não é suficiente para que um pequeno partido expanda sua votação e aumente suas chances de eleger candidatos e de adquirir maior relevância no jogo político.

Fixar-se em muitos municípios garante, à legenda, a prerrogativa de disputar um número maior de pleitos, o que lhe fornece as bases para recrutar membros e candidatos bem como para angariar recursos. Porém, transformar esse capital organizativo em capital eleitoral não é um processo automático; e, como sugere o contraste entre os dados da Tabela 6 e os resultados eleitorais verificados anteriormente nos gráficos, esse processo está sujeito a outros fatores condicionantes. Um segundo aspecto que emerge na Tabela 6 diz respeito ao grau de institucionalização destes partidos. Somente os pequenos partidos de esquerda parecem ter efetuado algum esforço para consolidar suas comissóes em diretórios ao longo do tempo; mesmo assim, apresentam proporçôes muito altas de CPs. O único partido dentre eles que apresenta mais de 50\% de diretórios é o PSTU, que tem desempenhos mais fracos em eleiçôes. Os demais partidos de esquerda situam-se na faixa dos 70\% de CPs. As legendas personalistas e confessionais têm níveis muito baixos de institucionalização, nunca apresentando percentual de CPs inferior a 80\%. A única exceção a este padrão é o PSDC, que tem padrão semelhante aos pequenos partidos de esquerda, com cerca de $77 \%$ de CPs, mas também é um dos partidos com desempenho eleitoral baixo. Além disso, o partido tem em comum com as pequenas legendas de esquerda o baixo número de estruturas organizacionais.

Os dados da Tabela 6 sugerem, em sintonia com a premissa de $\mathrm{Pa}$ nebianco (2005), que essas legendas operam com alto grau de liberdade no sistema político, pois seus diretórios nacionais são soberanos e podem interferir nas decisôes relativas ao jogo político-eleitoral municipal com grande autonomia. Além disso, como atesta Guarnieri (2011), partidos mais centralizados têm maior probabilidade de formar coalizóes em detrimento de lançar candidaturas próprias com poucas chances de vitória, o que explicaria o desempenho relativamente pior nas disputas para cargos executivos. As implicaçôes disso são significativas e indicam que os pequenos partidos podem atuar de maneira extremamente estratégica e 
flexível no contexto político brasileiro, utilizando-se dessa autonomia para maximizar votos e cargos de acordo com seu diagnóstico do cenário eleitoral. Os grandes partidos, por possuírem maior quantidade de recursos e maior máquina eleitoral, se estruturam de forma a garantir que esses sejam potencializados. Os pequenos partidos, por outro lado, devem levar em conta sua escassez de recursos e menor capilaridade, o que torna relevante a necessidade de exercer maior controle sobre suas subunidades, visando a garantir maior eficiência de suas estratégias e de seu comportamento.

Outro aspecto que merece ser ressaltado diz respeito ao que Braga e Silveira (2012) observam acerca da importância das bases territoriais para os jogos de poder internos dos partidos políticos. Os autores afirmam que os órgãos locais, além de serem eventualmente mobilizados por líderes e/ ou facçôes partidárias nas disputas internas das legendas, também servem como mecanismos de articulação de alianças no nível local, almejando objetivos nos níveis estaduais ou nacional. Isso poderia explicar, em parte, o fato de que pequenos partidos personalistas têm capilaridade relativamente alta, mas desempenho mediano. Para esses partidos, a presença em um número grande de municípios se justifica na medida em que expande as possibilidades de realização de coalizóes e acordos com legendas maiores, já que podem oferecer o apoio de suas bases locais em troca de acordos que lhes beneficiem em outras esferas eleitorais, ou mesmo na indicação para cargos políticos após a eleição.

\section{Perspectivas para o futuro}

Ao fim e ao cabo, os órgãos municipais são a base a partir da qual os partidos constroem as máquinas eleitorais que lhes possibilitarão expandir sua votação e o número de cargos conquistados. Essa é uma dimensão particularmente relevante nas disputas pelos legislativos estaduais e federal. Quanto maior for a presença de um partido nos municípios de um estado, maiores serão suas bases de campanha e maior será o número de candidatos de que ele irá dispor para lançar em suas listas, uma vez que cada novo órgão pressupóe o alistamento de novos membros. Ao aumentar o número de candidatos, o partido passa a obter uma quantidade maior de votos "no varejo", pois as votaçóes obtidas por eles, conquanto pequenas, se acrescentam àquela do partido com base na qual é realizado o cálculo eleitoral. 
Quando complementada com a costura de coligaçôes competitivas nos distritos eleitorais, essa estratégia pode aumentar o número de postos obtidos pelos pequenos partidos e, por conseguinte, aumentar sua relevância no jogo político.

O imperativo da expansão territorial convive de forma tensa com a necessidade que muitas lideranças têm de controlar a legenda. Nesse sentido, a baixa institucionalização, ilustrada pela prevalência de comissôes provisórias e interventoras, sugere que a direção nacional - e em alguns casos ela é exercida de facto por um único indivíduo - tem grande margem de ingerência nos órgãos subordinados, podendo controlar até mesmo a expansão territorial do partido. Como o desenvolvimento organizacional da legenda pode, em alguns casos, ser conflitante com os objetivos imediatos destas lideranças, as perspectivas de que os pequenos partidos se expandam e adquiram maior relevância são incertas.

Isso é especialmente verdade no caso dos pequenos partidos personalistas, que servem muitas vezes apenas como máquinas eleitorais para um número restrito de quadros políticos e seguem os desígnios de seus presidentes. Para este grupo de partidos, o foco na conquista de cargos acaba sendo um estímulo contrário à sua institucionalização, pois eles precisam operar apenas com uma base mínima necessária para promover um número reduzido de candidatos. Por não disporem de um projeto político para o país, é pouco provável que estas legendas adotem estratégias para a ampliação de suas bases territoriais e de seu número de filiados. Estas tenderão a se ampliar apenas de forma lenta e na medida em que o partido se instalar em municípios onde também recrutará candidatos. Assim, é pouco provável que os partidos personalistas adquiram maior relevância no cenário político brasileiro. A tendência é que eles sigam apresentando um desempenho fraco com aumento esporádico de bancadas, mas não a ponto de se consolidarem e se expandirem.

Os pequenos partidos de esquerda partilham da mesma perspectiva; mas, por motivos muito diferentes. Este grupo de legendas é pautado pela promoção de um conjunto de ideais cujo fim último é a transformação radical da sociedade. Dessa forma, concebem a si mesmos como instituiçóes de vanguarda no âmbito da sociedade, cujo papel é servir de guia do povo na luta pela implementação de um sistema socialista. Esta visão, formulada 
por Lênin (1961), requer destes partidos um trabalho intenso e permanente de mobilização dos eleitores, o que explica a ênfase dada aos órgãos de base. As eleiçóes são vistas sob uma lógica puramente estratégica de promoção da mensagem do partido e a maximização de votos e conquista de cargos não fazem parte do horizonte destas legendas. Em tese, este perfil gera muitos incentivos para que o partido expanda suas bases e se desenvolva organizacionalmente. Contudo, conforme os dados apontam, isso não tem ocorrido e estas legendas não possuem número grande de filiados, órgãos partidários e, consequentemente, apoio eleitoral. Em boa medida, esse fato pode ser creditado ao radicalismo de sua mensagem ideológica, que, sobretudo após o fim da União das Repúblicas Socialistas Soviéticas (URSS), tornou-se anacrônica no mundo contemporâneo. Assim, apesar de todo esforço de mobilização realizado pelos pequenos partidos de esquerda, é o conteúdo de sua mensagem e o radicalismo com que eles a difundem que acaba por limitar suas chances de sucesso.

Situação diferente é aquela vivida pelo PSOL, um partido de origem parlamentar que tem conseguido crescer e ampliar sua presença e influência na política brasileira. Ao contrário de seus congêneres, o PSOL opera dentro do jogo democrático e se coloca como um partido desafiante pela esquerda do espectro ideológico. Assim, as eleições e a conquista de cargos são vistos como forma legítima e eficaz de perseguir os objetivos do partido. Isso determina um perfil mais flexível por parte de seus membros. Enquanto os demais partidos de esquerda pregam a ortodoxia, o PSOL adota um discurso em sintonia com os movimentos sociais e as novas pautas da esquerda, de natureza pós-materialista. Suas perspectivas, portanto, são mais positivas. A tendência é que o partido cresça e se desenvolva organizacionalmente, ampliando sua presença no território e seu número de filiados.

As legendas confessionais têm apresentado o melhor desempenho entre os pequenos partidos, mas também é possível identificar divisôes entre elas. Um primeiro grupo é formado por PRB e PSC, partidos de origem parlamentar que ampliaram consideravelmente suas bancadas nos legislativos municipais, estaduais e federal, além de terem obtido número crescente de prefeituras. Essa trajetória é fruto tanto de sua expansão e desenvolvimento organizacional - são os partidos com maior número de filiados 
e órgãos partidários - quanto de sua estratégia de inserção social. Como visto, a relação dos partidos com organizações religiosas é tal que elas funcionam muitas vezes como instituiçóes informais (FREIDENBERG; LEVITSKY, 2006) por meio das quais eles obtêm apoio para seus candidatos e estabelecem vínculos sociais importantes. Ademais, adotam políticas de aliança bastante eficientes. $\mathrm{O}$ PRB, por exemplo, integrou a coligação mais forte em Sáo Paulo, com o PSDB, mesmo fazendo parte da base aliada do PT no âmbito nacional.

A atuação de seus membros eleitos tem ganhado bastante visibilidade, tanto que estes partidos formaram um dos grupos mais influentes no Congresso: a bancada evangélica. Isso certamente lhes garante ainda mais capital político e eleitoral. As duas legendas equilibram as dimensóes policy seeking ${ }^{11}$ e vote seeking, pois, para elas, a obtenção dos objetivos programático-ideológicos se efetiva pela atuação de seus membros nas instituiçóes representativas e de governo. Assim, as eleições são vistas como meio eficaz para a promoção das políticas que eles defendem.

O PSDC, por outro lado, é uma das legendas menos desenvolvidas, com número pequeno de filiados e de órgãos partidários. Em parte, isso se deve ao forte controle exercido por seu presidente e fundador José Maria Eymael, que faz com que o partido opere na mesma lógica das legendas personalistas, a despeito de seu conteúdo ideológico-programático religioso. Outro fator que explica seu desempenho fraco é seu vínculo com a Igreja Católica, que não lhe garante o mesmo apoio e uma capacidade de mobilização e criação de vínculos similar àquela obtida junto a instituiçóes evangélicas. Dessa forma, enquanto PRB e PSC tendem a se consolidar e expandir sua influência na política brasileira, o PSDC terá trajetória semelhante àquela dos pequenos partidos personalistas, ou seja, desempenho fraco e poucos incentivos ao desenvolvimento e expansão.

\section{Considerações finais}

Este artigo se propôs a traçar um panorama dos pequenos partidos brasileiros mediante a análise de sua trajetória eleitoral e do uso de

I Perfil tipológico de partidos orientados principalmente para a implementação de determinados tipos de políticas públicas. 
categorias tipológicas (EV, 2015) que os definem para explicar suas distintas performances. Discutiu-se o problema de como definir o tamanho dos partidos e as distintas estratégias encontradas na literatura para classificar as legendas brasileiras quanto à sua relevância. A opção feita no âmbito deste trabalho foi por adotar um limiar percentual de votos para a Câmara dos Deputados no período delimitado (1998-2014), a partir do qual se identificou um conjunto de 15 legendas consideradas pequenas relativamente às demais.

A partir da definiçáo das legendas, a análise empreendida reportou os dados relativos à performance eleitoral dos pequenos partidos em eleiçôes para o legislativo e o executivo nos níveis municipal, estadual e nacional. Em seguida, explorou-se em que medida as distinçóes ideológicas e organizacionais entre os pequenos partidos poderiam explicar seus variados desempenhos eleitorais. Por fim, foram projetadas as chances de sucesso futuro dos distintos grupos de legendas e indicadas aquelas com maior potencial de ascenderem a patamares de maior relevância no sistema político brasileiro.

Dessa forma, espera-se ter contribuído para o estudo deste grupo de atores do sistema partidário que, até o momento, continua sendo pouco conhecido da ciência política brasileira. A análise aqui empreendida visa a fomentar o debate e ulteriores estudos acerca dos pequenos partidos. Procurou-se introduzir uma nova dimensão de análise destas legendas para além do viés mais comum de análise, em geral focado em como elas se beneficiam da estratégia de coalizóes eleitorais. Argumenta-se que a expansão territorial e o grau de controle sobre os níveis subnacionais também podem estar relacionados ao sucesso ou não de seus esforços eleitorais.

\section{Referências}

BAQUERO, M.; VASCONCELOS, C. Crise de representação política, o surgimento da antipolítica e os movimentos antipartidarismo no Brasil. In: ENCONTRO DO COMPOLÍTICA, 5., 8-10 maio 2013, Curitiba. Anais [....]. Curitiba: COMPOLÍTICA, 2013. p. 1-21.

BRAGA, M. S.; SILVEIRA, R. Organizacion, Territorio Y Sistema Partidario: Difusion Territorial De La Organizacion De Los Partidos Y Sus Potenciales Impactos Sobre La Estructura Del Sistema Partidario En Brasil. America Latina Hoy, v. 62, p. 15-45, 2012. 
CALVO, E.; GUARNIERI, F.; LIMONGI, F. Why Coalitons? Party system fragmentation, small party bias, and preferential voting in Brazil. Electoral Studies, n. 39, p. 219-229, 2015. Disponível em: http://dx.doi.org/10.1016/j.electstud.2015.03.012. Acesso em: 11 ago. 2018.

DANTAS, H.; PRAÇA, S. Pequenos partidos nas coligações eleitorais para prefeituras em 2000. Leviathan, Sáo Paulo, n. 1, p. 181-200, 2004.

DANTAS, H.; PRAÇA, S. Pequenos partidos no Brasil: uma análise do posicionamento ideológico com base nas coligações municipais de 2000 a 2008. In: KRAUSE, S.; DANTAS, H.; MIGUEL, L. F. (Ed.). Coligaçóes partidárias na nova democracia brasileira: perfis e tendências. São Paulo: Ed. Unesp. p. 99-133.

DOWNS, A. Uma Teoria Econômica da Democracia. São Paulo: Edusp, 1999.

DUVERGER, M. Os Partidos Políticos. São Paulo: Zahar, 1980.

EV, L. S. Quem sáo e pelo que competem os pequenos partidos brasileiros? Orientador: ?. CARLOS RANULFO FÉLIX DE MELO 2015. 150 f. Dissertação (Mestrado em Ciência Política) - Programa de Pós-Graduação em Ciência Política, Universidade Federal de Minas Gerais, Belo Horizonte, 2015.

EV, L. S.; MELO, P. V. De onde vem e como sobrevivem os nanicos? Analise da votação dos pequenos partidos brasileiros. In: ENCONTRO DA ASSOCIAÇÃO NACIONAL DE PÓSGRADUAÇÃO E PESQUISA EM CIÊNCIAS SOCIAIS - ANPOCS, 38., Caxambu. Anais eletrônicos [...]. Caxambu: ANPOCS, 2014. Disponível em: http://opiniaopublica.ufmg.br/ site/files/biblioteca/EV-e-MELO-De-onde-vem-e-como-sobrevivem-os-nanicos-ANPOCS1.pdf. Acesso em: 2 ago. 2018.

FREIDENBERG, F.; LEVITSKY, S. Informal Institutions and Party Organization in Latin America. In: HELMKE, G.; LEVITSKY, S. (Org.). Informal Institutions and Democracy. Lessons from Latin America. Baltimore: The Johns Hopkins University Press. 2006. p.178-200?

GUARNIERI, F. A força dos partidos 'fracos'. Dados, Rio de Janeiro, v. 54, n. 1, p. 235-258, 2011.

INSTITUTO BRASILEIRO DE GEOGRAFIA E ESTATÍSTICA (IBGE). Censo Brasileiro de 2010. Disponível em:

https://www.ibge.gov.br/estatisticas/sociais/populacao/9662-censo-demografico-2010. html?edicao $=9673 \& \mathrm{t}=$ destaques. Acesso em: 2 jul. 2018.

LACERDA, D. F.; MOURA, P. As Razões da Esquerda Radical: eleições e organização partidária em um extremo ideológico. In: VII ENCONTRO DA ASSOCIAÇÃO BRASILEIRA DE CIÊNCIA POLÍTICA - ABCP 2010, 7., ? . Anais [...]. : RECIFE ABCP, 2010.

MELO, C. R. Retirando as Cadeiras do Lugar: migração partidária na Câmara dos Deputados (1985/2002). Belo Horizonte: Editora UFMG, 2004. 
MELO, P. V. T. P. O PMDB e sua Manutençáo no Centro do Jogo Político: de catch-all a cartel. Orientador: ?.HELCIMARA DE SOUZA TELLES 2015. 00205 f. Dissertação (Mestrado em Ciência Política) - Programa de Pós-Graduação em Ciência Política, Universidade Federal de Minas Gerais, Belo Horizonte, 2013.

NASCIMENTO, W.; SILVA JÚNIOR, J. A.; PARANHOS, R.; SILVA, D.; FIGUEIREDO FILHO, D. B. Does size matter? Electoral performance of small parties in Brazil. Brazilian Political Science Review, v. 10, n. 2, p. 1-26, 2016.

PAIVA, D.; ALVES, V. S.; BENEDITO, S. M. As coligaçóes proporcionais e os pequenos partidos nas eleições para a Câmara dos Deputados 1998-2014. In: KRAUSE, S.; MACHADO, C.; MIGUEL, L. F. (Org.) Coligaçóes e Disputas Eleitorais na Nova República: Aportes teóricometodológicos, tendências e estudos de caso. Rio de Janeiro: Fundação Konrad Adenauer/São Paulo: Editora Unesp, 2017. p.?321-364

PANEBIANCO, A. Modelos de Partido. São Paulo: Martins Fontes, 2005.

RODRIGUES, L. M. As Eleições de 1994: Uma Apreciação Geral. Dados, Rio de Janeiro, v. 38, n. 1, p.?, 93-106.1995.

SARTORI, G. Partidos e Sistemas Partidários. Brasília: Editora UNB, 1976.

SILVA, L.; DOMINGOS, A.; CUNHA, M.; TORRES, M.; NASCIMENTO, W. Altruístas ou oportunistas? Uma análise dos pequenos partidos nas coligaçōes eleitorais (1998-2014). E-Legis

- Revista Eletrônica do Programa de Pós-Graduaçáo da Câmara dos Deputados, [S. 1.], p. 45-61, dez. 2016. Disponível em: http://e-legis.camara.leg.br/cefor/index.php/e-legis/article/ view/274/365. Acesso em: 11 ago. 2018.

TRIBUNAL SUPERIOR ELEITORAL (TSE).

TRIBUNAL SUPERIOR ELEITORAL (TSE). Partidos políticos registrados no TSE. 2018. Disponível em: http://www.tse.jus.br/partidos/partidos-politicos/registrados-no-tse. Acesso em: 15 ago. 2018 .

UNIVERSIDADE FEDERAL DE MINAS GERAIS (UFMG). Centro de Estudos Legislativos. 


\section{Small Parties and electoral disputes in Brazil: a performance analysis between 1998 and 2014}

\section{Abstract}

This article aims to contribute to the study of small Brazilian parties by analyzing their performances in elections and their organizational characteristics. It presents the discussion of possible criteria of how to establish which are the small parties and proposes one according to which the cases are selected. Electoral data on executive and legislative disputes at the three federative levels of the selected party group are analyzed and the different performances of the small parties are related to their organizational characteristics. The analysis shows that the parties with the greatest capillarity and less institutionalization of their sub-national directories have performed better in the analyzed period.

Keywords: Small Parties; Elections; Party System

Recebido em 31/08/2018

Aprovado em 26/08/2019 